\title{
Simulation study for measurement of horizontal wind profiles in the polar stratosphere and mesosphere using ground-based observations of ozone and carbon monoxide lines in the $230-250 \mathrm{GHz}$ region
}

\author{
David A. Newnham ${ }^{1}$, George P. Ford ${ }^{1, \text { a }}$, Tracy Moffat-Griffin ${ }^{1}$, and Hugh C. Pumphrey ${ }^{2}$ \\ ${ }^{1}$ British Antarctic Survey, High Cross, Madingley Road, Cambridge, CB3 0ET, UK \\ ${ }^{2}$ School of GeoSciences, University of Edinburgh, Edinburgh, EH9 3FF, UK \\ anow at: Met Office, FitzRoy Road, Exeter, Devon, EX1 3PB, UK
}

Correspondence to: David A. Newnham (dawn@bas.ac.uk)

Received: 23 December 2015 - Published in Atmos. Meas. Tech. Discuss.: 18 January 2016

Revised: 10 June 2016 - Accepted: 13 June 2016 - Published: 26 July 2016

\begin{abstract}
Meteorological and atmospheric models are being extended up to $80 \mathrm{~km}$ altitude but there are very few observing techniques that can measure stratospheric-mesospheric winds at altitudes between 20 and $80 \mathrm{~km}$ to verify model datasets. Here we demonstrate the feasibility of horizontal wind profile measurements using ground-based passive millimetre-wave spectroradiometric observations of ozone lines centred at 231.28, 249.79, and $249.96 \mathrm{GHz}$. Vertical profiles of horizontal winds are retrieved from forward and inverse modelling simulations of the line-of-sight Dopplershifted atmospheric emission lines above Halley station $\left(75^{\circ} 37^{\prime} \mathrm{S}, 26^{\circ} 14^{\prime} \mathrm{W}\right)$, Antarctica. For a radiometer with a system temperature of $1400 \mathrm{~K}$ and $30 \mathrm{kHz}$ spectral resolution observing the ozone $231.28 \mathrm{GHz}$ line we estimate that $12 \mathrm{~h}$ zonal and meridional wind profiles could be determined over the altitude range $25-74 \mathrm{~km}$ in winter, and $28-66 \mathrm{~km}$ in summer. Height-dependent measurement uncertainties are in the range $3-8 \mathrm{~m} \mathrm{~s}^{-1}$ and vertical resolution $\sim 8-16 \mathrm{~km}$. Under optimum observing conditions at Halley a temporal resolution of $1.5 \mathrm{~h}$ for measuring either zonal or meridional winds is possible, reducing to $0.5 \mathrm{~h}$ for a radiometer with a $700 \mathrm{~K}$ system temperature. Combining observations of the 231.28 GHz ozone line and the $230.54 \mathrm{GHz}$ carbon monoxide line gives additional altitude coverage at $85 \pm 12 \mathrm{~km}$. The effects of clear-sky seasonal mean winter/summer conditions, zenith angle of the received atmospheric emission, and spectrometer frequency resolution on the altitude coverage, measurement uncertainty, and height and time resolution of the retrieved wind profiles have been determined.
\end{abstract}

\section{Introduction}

The measurement of horizontal wind profiles in the 20 $70 \mathrm{~km}$ altitude range remains a challenge for atmospheric science. Although a variety of in situ and remote sensing techniques, summarised in Fig. 1, are available for observing winds in the troposphere, lower stratosphere, and lower thermosphere the routine measurement of upper stratospheric and mesospheric winds have been difficult to obtain.

Ground-based radar systems such as meteor radars (Maekawa et al., 1993; Jacobi et al., 2007; Hoffmann et al., 2007), incoherent scatter radars (Alcaydé and Fontanari, 1986; Nicolls et al., 2010) and medium frequency radars (Briggs, 1980; Hoffmann et al., 2007) profile winds down to $70 \mathrm{~km}$. mesosphere-stratosphere-troposphere (MST) radar techniques (e.g. Hooper et al., 2008; Lee et al., 2014) provide additional coverage over 0-20 km. Under clear-sky conditions the Rayleigh-Mie-Raman (RMR) lidar (Baumgarten, 2010; Hildebrand et al., 2012) measures winds throughout the middle atmosphere above Andenes, northern Norway but requires complex laser transmission and detection equipment and is not portable. Ground-based Doppler lidars measure tropospheric and lower stratospheric winds (Gentry et al., 2000), with possible extension up to $50 \mathrm{~km}$ (Souprayen et al., 1999) and sodium lidars cover the altitude range $85-100 \mathrm{~km}$ (Williams et al., 2004). The ground-based E-region wind interferometer (ERWIN) measured upper atmospheric winds at three altitudes near the mesopause using airglow emissions from electronically excited atomic oxygen $\mathrm{O}\left({ }^{1} \mathrm{~S}\right), \mathrm{OH}$, and molecular oxygen $\left(\mathrm{O}_{2}\right)$ (Gault et al., 1996a). Balloon- 


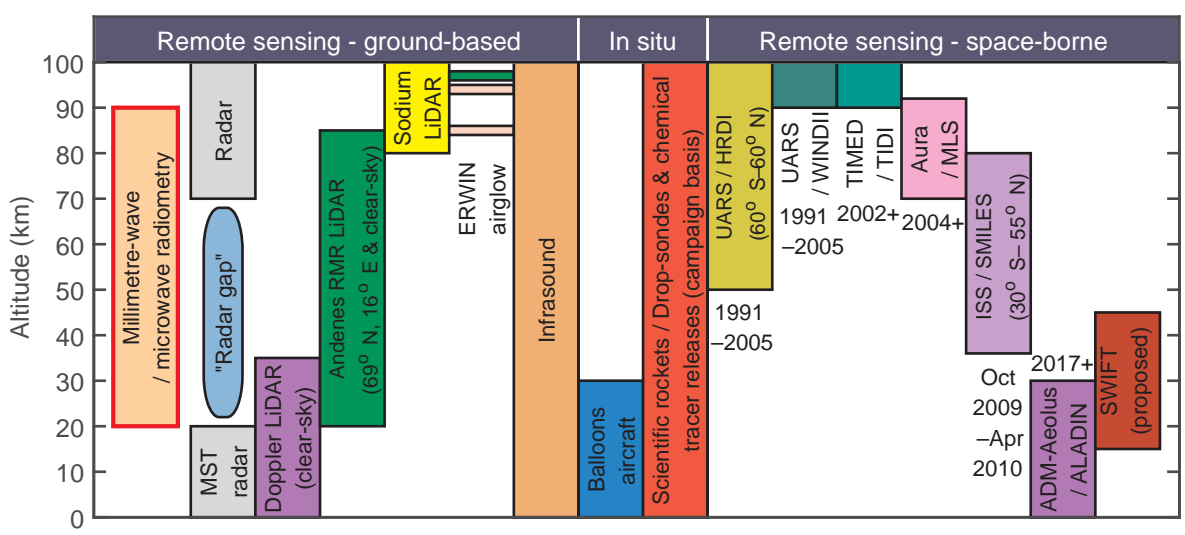

Figure 1. Overview of atmospheric wind measurement techniques with their altitude coverage. For space-borne sensors the abbreviations for the satellite/instrument names are given with years of operation.

borne radiosondes provide detailed wind measurements in the troposphere and lower stratosphere (e.g. Hibbins et al., 2005). Rockets can deploy falling targets tracked by radar (Müllemann and Lübken, 2005), or chemical tracers (Chu et al., 2007), but such campaigns are expensive and unsuitable for long-term monitoring. Infrasound measurements are used for investigating wind velocity variations in the stratosphere, mesosphere, and lower thermosphere (e.g. Le Pichon et al., 2010; Assink et al., 2012, 2013; Chunchuzov et al., 2015).

Over a 14-year period the space-borne high-resolution Doppler imager (HRDI) (Burrage et al., 1996) measured wind velocities typically between $60^{\circ} \mathrm{N}$ and $60^{\circ} \mathrm{S}$ and down to $50 \mathrm{~km}$ and contributed to the Upper Atmosphere Research Satellite (UARS) Reference Atmosphere Project (URAP) (Swinbank and Ortland, 2003) wind climatology. Also on UARS, the limb-sounding WIND Imaging Interferometer (WINDII) observed $\mathrm{O}\left({ }^{1} \mathrm{~S}\right)$ airglow emission to measure winds over 90-110 km (Gault et al., 1996b). Since 2002 the TIMED Doppler Interferometer (TIDI) has been making limb-scanning measurements of $\mathrm{O}\left({ }^{1} \mathrm{~S}\right)$ and $\mathrm{O}_{2}(0-0)$ band emissions for determining horizontal winds above $60 \mathrm{~km}$ (Killeen et al., 2006). Satellite measurements of mesospheric winds down to $80 \mathrm{~km}$ were determined from Aura Microwave Limb Sounder (MLS) observations of Doppler-shifted, Zeeman-split $\mathrm{O}_{2} \sigma^{-}$and $\sigma^{+}$ lines around $118.75 \mathrm{GHz}(\mathrm{Wu}$ et al., 2008). Winds at 35$80 \mathrm{~km}$ were observed for a limited time over the latitude range $30^{\circ} \mathrm{S}$ to $55^{\circ} \mathrm{N}$ using ozone $\left(\mathrm{O}_{3}\right)$ and hydrogen chloride emission line measurements in the $625-650 \mathrm{GHz}$ range by the Submillimeter-Wave Limb-Emission Sounder (SMILES) (Baron et al., 2013). The Atmospheric Laser Doppler Instrument (ALADIN) on the forthcoming Atmospheric Dynamics Mission (ADM) Aeolus satellite will make UV lidar measurements of winds in the troposphere and lower stratosphere (Stoffelen et al., 2005). The aim of the planned Stratospheric Wind Interferometer for Transport studies (SWIFT) is to make global measurements of middle stratospheric winds be- tween 15 and $50 \mathrm{~km}$ using $8 \mu \mathrm{m} \mathrm{O} \mathrm{O}_{3}$ emission lines (McDade et al., 2001; Shepherd et al., 2001).

For the reasons outlined above, global models such as the semi-empirical Horizontal Wind Model (HWM) (Drob et al., 2008, 2015) and reanalysis datasets such as the European Centre for Medium-Range Weather Forecasts (ECMWF) operational analyses (Dee et al., 2011) and NASAs ModernEra Retrospective Analysis for Research and Applications (MERRA) (Rienecker et al., 2011) contain sparse information based on observations above $20 \mathrm{~km}$, in contrast to the widespread operational data for the lower atmosphere. Systematic comparisons between co-located ground-based wind radiometer, lidar, and infrasound observations and reanalysis data found both temperature and horizontal wind speeds deviate increasingly above $40 \mathrm{~km}$ as the assimilated observations became sparser (Le Pichon et al., 2015). Between altitudes of 40 to $60 \mathrm{~km}$ the standard deviation of the mean difference in zonal winds exceeds $20 \mathrm{~m} \mathrm{~s}^{-1}$ with the largest differences in winter when variability associated with large-scale planetary waves dominates. High-latitude mesospheric horizontal winds in HWM-07 (Drob et al., 2008) have standard deviations greater than $25 \mathrm{~m} \mathrm{~s}^{-1}$ and significant differences with observed zonal and meridional winds above $80 \mathrm{~km}$ (Sandford et al., 2010). With ECMWF producing specifications based on temperature soundings up to $75 \mathrm{~km}$ and fully assimilative high-top global circulation models being extended into the thermosphere, there is considerable urgency to verify the mean horizontal winds in models and meteorological (re)analyses. Superimposed on the mean flow are atmospheric tides and vertically propagating waves that influence the planetary-scale circulation of the stratosphere, drive mesospheric circulation, and drive chemical transport and temperature gradients through pole-pole meridional circulation, turbulent mixing, and diffusion (Brasseur and Solomon, 2005; Holton, 2004). These impact on the stability of the northern and southern hemisphere polar vortices where abrupt changes or even reversals of strong zonal winds 
during sudden stratospheric warming (SSW) events lead to strong dynamical and chemical coupling between the lower and upper atmosphere (Manney et al., 2008). New wind observing techniques for the polar regions are essential to better understand and parameterise these processes in circulation models for climate studies and numerical weather prediction.

Attention has recently turned to using ground-based microwave and sub-millimetre Doppler spectroradiometry to provide measurements of horizontal wind profiles covering the altitude range $30-85 \mathrm{~km}$. By measuring the Doppler frequency shift of passive emission due to a rotational transition by a selected atmospheric molecule the line-of-sight wind speed can be determined (Clancy and Muhleman, 1993). The magnitude of the shift $\Delta v$ (in units of $\mathrm{Hz}$ ) depends both on the wind speed along the line-of-sight (LOS) of the detector, $v_{\mathrm{LOS}}\left(\right.$ in $\mathrm{m} \mathrm{s}^{-1}$ ), and the rest frame frequency of the line, $v_{0}$ (in $\mathrm{Hz}$ ):

$\Delta v=\frac{v_{\mathrm{LOS}}}{c} v_{0}$,

where $c$ is the speed of light (in $\mathrm{m} \mathrm{s}^{-1}$ ). The horizontal wind speed (in $\mathrm{m} \mathrm{s}^{-1}$ ) is given by

$v_{\text {wind }}=v_{\text {LOS }} \sec \varepsilon$,

where $\varepsilon$ is the zenith angle of the ground-based observation. By taking measurements of the Doppler shifts from perpendicular azimuthal directions the zonal and meridional wind components are determined, and measurement biases on each component can be removed using measurements taken in opposite directions. The frequency shifts are small, in the range 5 to $200 \mathrm{kHz}$, but can be measured precisely using stable, high-resolution digital fast Fourier transform spectrometers (Klein et al., 2012). Wind speeds at $70-85 \mathrm{~km}$ above the South Pole were determined with uncertainty $\pm 5 \mathrm{~m} \mathrm{~s}^{-1}$ by observing the carbon monoxide (CO) line at $461 \mathrm{GHz}$ (Burrows et al., 2007). Rüfenacht et al. (2012, 2014) used observations of the $\mathrm{O}_{3}$ microwave emission line at $142.18 \mathrm{GHz}$ by the ground-based wind radiometer (WIRA), and optimal estimation retrieval, to measure daily mean zonal and meridional wind profiles. Comparison of their measured time series from four locations at polar, mid-, and tropical latitudes with ECMWF model data showed that meridional and zonal stratospheric winds agreed to within $10 \%$. However in the mesosphere, above $40-50 \mathrm{~km}$, observed and modelled zonal wind speeds differ significantly by up to $50 \%$ (Rüfenacht et al., 2014).

The aim of this work is to investigate the potential for retrieving wind speeds from ground-based $230-250 \mathrm{GHz}$ radiometer observations of the polar atmosphere. Potential advantages of radiometry at these intermediate frequencies, in-between the microwave and sub-millimetre, include larger Doppler shifts than in the microwave, lower atmospheric opacity and signal attenuation and smaller Doppler line widths than in the sub-millimetre, and numerous isolated or overlapping $\mathrm{O}_{3}$ emission lines and a $\mathrm{CO}$ line centred at $230.54 \mathrm{GHz}$. The $\mathrm{O}_{3} 231.28 \mathrm{GHz}$ line intensity $\left(4.846 \times 10^{-23} \mathrm{~cm} \mathrm{molecule}^{-1}\right.$ at $\left.296 \mathrm{~K}\right)$ is over twice that for the $142.18 \mathrm{GHz}$ line $\left(2.346 \times 10^{-23} \mathrm{~cm} \mathrm{molecule}^{-1}\right.$ at $296 \mathrm{~K}$ ), producing a more intense emission signal at source. We perform calculations for simulated wind retrievals above Halley station, Antarctica. Studies of mean winds, gravity waves, planetary waves, and atmospheric tides have utilised radiosonde balloon, imaging Doppler interferometer, and $\mathrm{Su}-$ perDARN radar observations from Halley (Hibbins et al., 2006, 2009; Nielsen et al., 2012). These observations have been limited to the troposphere, lower stratosphere, and upper mesosphere; co-located radiometric measurements could provide complementary observations filling the gap in altitudes at $25-75 \mathrm{~km}$. In Sect. 2 the methodology for simulating millimetre-wave atmospheric spectra and performing wind retrievals is described. In Sect. 3 we present the wind retrieval results for different atmospheric conditions and radiometer instrument configurations, and the main conclusions are summarised in Sect. 4.

\section{Methodology}

\subsection{Ground-based radiometer instrument and location}

Atmospheric observations are simulated for a groundbased millimetre-wave radiometer located at Halley station $\left(75^{\circ} 37^{\prime} \mathrm{S}, 26^{\circ} 14^{\prime} \mathrm{W}, 43 \mathrm{~m}\right.$ above mean sea level), Antarctica. The instrument characteristics and performance are based on an existing total power radiometer (Espy et al., 2006; Newnham et al., 2011; Straub et al., 2013; Daae et al., 2014), a relatively portable and robust instrument that has been deployed in the polar regions for semi-autonomous, continuous yearround operation. This instrument utilises a superconductorinsulator-superconductor (SIS) mixer at $4 \mathrm{~K}$ and low-noise amplifiers for sensitive heterodyne measurements of atmospheric spectra in the frequency region $230-250 \mathrm{GHz}$. Measurements by such a system achieve a single-sideband noise temperature of $200 \mathrm{~K}$ and a total system temperature of $1400 \mathrm{~K}$. We also assess how wind measurements would be improved by using radiometers with system temperatures of 700 and $1000 \mathrm{~K}$. Spectral analysis of the down-converted signal over a $300 \mathrm{MHz}$ bandwidth, centred on the emission line(s) of interest, and with channel widths $\geq 10 \mathrm{kHz}$ is based on the specifications of commercially available chirp transform and fast Fourier transform (FFT) spectrometers for radiofrequency (RF) analysis. Rüfenacht et al. (2014) showed for the WIRA instrument that frequency errors arising from reference oscillator instabilities and spectrum baseline artefacts such as standing waves are either small or can be adequately characterised to minimise their impact on the wind retrievals. However for other wind radiometers these effects could make a larger contribution to the measurement uncertainty that is not considered in the simulations here. For example, with instruments using a SIS mixer there is the po- 
tential for significant interfering reflections between cryostat windows and other optical components. The potential sources of such artefacts need to be identified at the instrument design and build stages and steps taken to reduce them to an acceptable level, e.g. through anti-reflection machining of optical surfaces and path-length modulation aimed at minimising standing wave amplitudes.

The radiometer is assumed to make total power measurements in turn of two calibration targets, one at ambient temperature and a cold reference load, and upward-viewing sky measurements at either two or four cardinal azimuthal directions and at a fixed zenith angle. If the duration of each measurement is $\sim 10 \mathrm{~s}$, allowing for receiver mirror repositioning in each viewing direction, then one complete measurement cycle taking $\sim 60 \mathrm{~s}$ would provide calibrated spectra in two azimuthally opposite directions, i.e. east and west for zonal wind and north and south for meridional wind determination. Integration of measured data over repeated calibration cycles increases the signal-to-noise ratio of the calibrated atmospheric spectra.

The zenith angle of the sky observation affects the wind measurement in a number of ways. At higher zenith viewing angles the LOS Doppler shift due to the horizontal movement of the observed air mass is increased. The atmospheric column of ozone or carbon monoxide molecules increases with zenith angle, with angles of 45,60 , and $80^{\circ}$ yielding geometric air mass factors of 1.4, 2.0, and 5.8 respectively. Atmospheric opacity will affect the wind measurement and may dominate at higher zenith angles under conditions of high precipitable water vapour (PWV).

At different slant angles the air mass observed, and its distance from the radiometer, will change. For a zenith angle of $45^{\circ}$, the distances on the ground between Halley and the intercepts at altitudes of 25,50 , and $75 \mathrm{~km}$ are 25,50 , and $75 \mathrm{~km}$, neglecting refraction, whereas at $80^{\circ}$ the distances are 142,284 , and $425 \mathrm{~km}$, respectively. Since the zonal and meridional wind retrievals are derived by combining radiometric measurements at opposing east-west or north-south directions, the choice of zenith angle will affect the spatial resolution of wind structures and atmospheric dynamical effects, as well as inter-comparisons with radiosonde, radar, and uniformly gridded reanalysis data. Halley is typically inside the Antarctic polar vortex, which can extend to $60^{\circ} \mathrm{S}$ (Turunen et al., 2009) meaning that wintertime observations, even at a zenith angle of $80^{\circ}$, would usually be well within the vortex edge. Halley station is on the Brunt Ice Shelf, a relatively flat location that would allow unobscured clear-sky views from the ground in all directions and at zenith angles reaching $80^{\circ}$ or higher. However, antenna sidelobes could adversely affect the radiometric calibration for atmospheric observations made at high zenith angles.

Figure 2 shows histograms of 6-hourly zonal and meridional wind data from ECMWF Interim re-analysis data (Dee et al., 2011) over the pressure (altitude) range $0.1-25 \mathrm{hPa}$ $(\sim 64-25 \mathrm{~km})$. The data are for $75.5^{\circ} \mathrm{S}, 26.5^{\circ} \mathrm{W}$, the grid

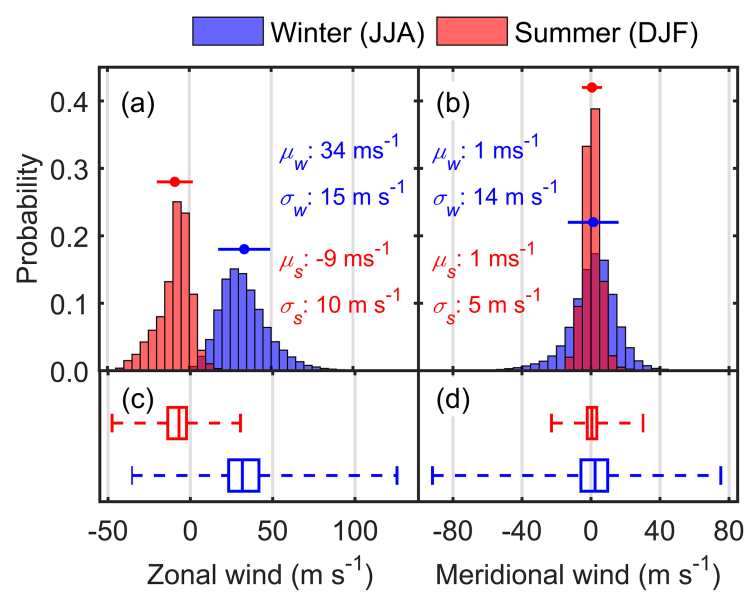

Figure 2. Histograms of (a) zonal and (b) meridional winds over the pressure range $0.1-25 \mathrm{hPa}(\sim 64-25 \mathrm{~km})$ in winter (JJA, blue) and summer (DJF, red) from 6-hourly ERA-interim data for 2009-2014 at grid-point $75.5^{\circ} \mathrm{S}, 26.5^{\circ} \mathrm{W}$. The horizontal error bars show the mean winds $\left(\mu_{\mathrm{W}}, \mu_{\mathrm{s}}\right)$ and standard deviations $\left(\sigma_{\mathrm{W}}, \sigma_{\mathrm{s}}\right)$ for winter (JJA) and summer (DJF) respectively. The corresponding boxplots of the (c) zonal and (d) meridional wind data indicate the minima, lower quartile (25th percentile), median, upper quartile (75th percentile), and maxima wind speeds. +ve zonal winds are eastwards and + ve meridional winds are northwards.

point closest to Halley, and cover the austral winter (June, July, August - JJA) and summer (December, January, February - DJF) periods over the 5-year period 2009-2014. The zonal winds in the middle atmosphere are predominantly westward in summer with mean speed $-9 \mathrm{~m} \mathrm{~s}^{-1}$ and more strongly eastward in winter with mean value $+34 \mathrm{~m} \mathrm{~s}^{-1}$. However the re-analysis data show a large range of zonal wind speeds, in particular during winter where wind speeds span -36 to $+126 \mathrm{~m} \mathrm{~s}^{-1}$. The meridional winds are lighter with mean values of $+1 \mathrm{~m} \mathrm{~s}^{-1}$ in both winter and summer. The winter meridional wind speeds show a large range from -92 to $+75 \mathrm{~m} \mathrm{~s}^{-1}$.

Wind speed gradients across the areas covered by measurements in opposite azimuthal directions will affect the zonal and meridional wind measurements. We have compared ECMWF Interim re-analysis zonal and meridional wind speed data for 2012 at the grid point closest to Halley with the corresponding data for grid points within the areas covered by measurements at zenith angles of 45,60 , and $80^{\circ}$. For zenith angle $45^{\circ}$ over altitudes $35-65 \mathrm{~km}$, and zenith angle $60^{\circ}$ below $50 \mathrm{~km}$, the mean difference in wind speeds is below $1 \mathrm{~m} \mathrm{~s}^{-1}$. For zenith angle $60^{\circ}$ and altitude $65 \mathrm{~km}$ the mean difference is $1.2 \mathrm{~m} \mathrm{~s}^{-1}$ in zonal wind and $1.6 \mathrm{~m} \mathrm{~s}^{-1}$ for meridional winds. At higher zenith angle the wind gradients are larger and increase with altitude as the coverage area expands. At $80^{\circ}$ zenith angle the mean differences in zonal winds at 35,50 , and $65 \mathrm{~km}$ altitude are 2.1 , 21.9 , and $26.8 \mathrm{~m} \mathrm{~s}^{-1}$, respectively. For meridional winds the corresponding values are $2.7,11.4$, and $16.7 \mathrm{~m} \mathrm{~s}^{-1}$. For both 
zonal and meridional winds the largest instantaneous zonal or meridional wind gradients approach $90 \mathrm{~m} \mathrm{~s}^{-1}$ at $65 \mathrm{~km}$ for $80^{\circ}$ zenith angle. Wind gradients across the area observed by wind radiometry could therefore have a significant effect on the retrieved wind speeds at higher zenith angles (above $60^{\circ}$ ) and in the mesosphere where the observed air masses are separated by hundreds of $\mathrm{km}$.

\subsection{Atmospheric spectra}

The clear-sky atmospheric spectrum in the $230-250 \mathrm{GHz}$ region above Halley is dominated by discrete $\mathrm{O}_{3}, \mathrm{O}_{2}$, and $\mathrm{CO}$ lines together with smoothly varying continua due to water vapour, oxygen, and nitrogen. Weak emission lines in this frequency range due to trace species such as nitric oxide and nitrogen dioxide are not included in our wind retrieval calculations. Winter (June, July, August - JJA) and summer (December, January, February - DJF) seasonal average profiles of $\mathrm{O}_{3}, \mathrm{CO}$, water vapour, $\mathrm{O}_{2}$, and temperature over the altitude range $0-120 \mathrm{~km}$ are calculated from 12 years of simulations by the Whole Atmosphere Community Climate Model with Specified Dynamics (SD-WACCM) version 3.5.48 (Garcia et al., 2007; Marsh, 2011; Lamarque et al., 2012). The profiles, calculated by combining the day-time and night-time SD-WACCM profiles at 74.8 and $76.7^{\circ} \mathrm{S}$, the gridded latitudes closest to Halley, according to the solar elevation angle at $72 \mathrm{~km}$ are shown in Fig. 3. The continuum contribution from molecular nitrogen uses standard sub-Arctic profiles. Compared to the summer case, wintertime $\mathrm{O}_{3} \mathrm{VMR}$ is higher in the secondary ozone layer centred at $10^{-3} \mathrm{hPa}(\sim 96 \mathrm{~km})$ and in the seasonal tertiary layer at $\sim 0.05 \mathrm{hPa}(\sim 70-75 \mathrm{~km})$. In summer $\mathrm{O}_{3} \mathrm{VMR}$ is higher in the upper stratosphere between $0.3-0.8 \mathrm{hPa}(\sim 54-$ $38 \mathrm{~km}$ ). Mesospheric CO VMR is higher in winter, due to strong descent in the southern polar vortex, but SD-WACCM may underestimate the seasonal $\mathrm{CO}$ variability observed by Aura MLS (Pumphrey et al., 2007). Higher summer mean temperatures and tropospheric water vapour VMR lead to increased PWV and atmospheric opacity at millimetre wavelengths. For Halley the mean PWV calculated from the SDWACCM data is $6.58 \mathrm{~mm}$ in summer and $1.18 \mathrm{~mm}$ in winter. The lower quartile PWV in winter is $0.92 \mathrm{~mm}$, i.e. for $25 \%$ of the time during winter months (JJA) PWV is at this value or lower with a mean value of $0.76 \mathrm{~mm}$.

The Atmospheric Radiative Transfer Simulator (ARTS) (version 2.2.0) available at http://www.radiativetransfer.org/ is the forward model used in this study (Buehler et al., 2005; Eriksson et al., 2011). ARTS is a line-by-line model that can simulate radiances from the infrared to the microwave, and has been validated against other models in the millimetre spectral range (Melsheimer et al., 2005). It includes contributions from spectral lines and continua via a choice of user-specified parameterisations. For our work, we use the Planck formalism for calculating brightness temperatures and spectroscopic line parameters are taken from the high-

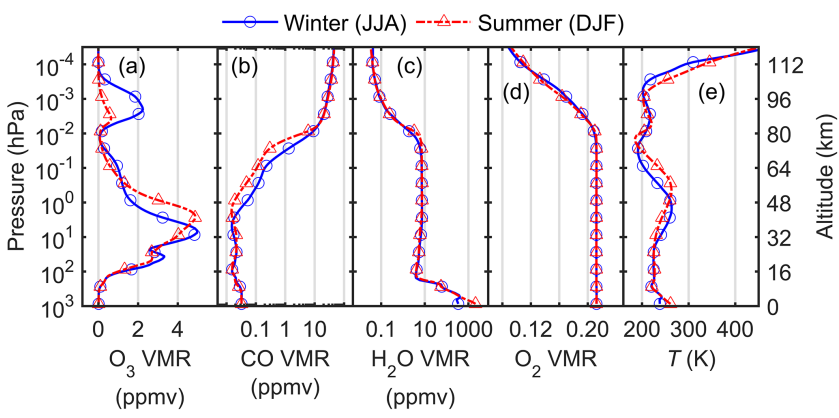

Figure 3. Seasonal mean winter (JJA, solid blue line) and summer (DJF, dashed red line) atmospheric profiles for (a) $\mathrm{O}_{3} \mathrm{VMR}$, (b) $\mathrm{CO}$ $\mathrm{VMR}$, (c) water vapour VMR, (d) $\mathrm{O}_{2} \mathrm{VMR}$, and (e) temperature from SD-WACCM simulation data.

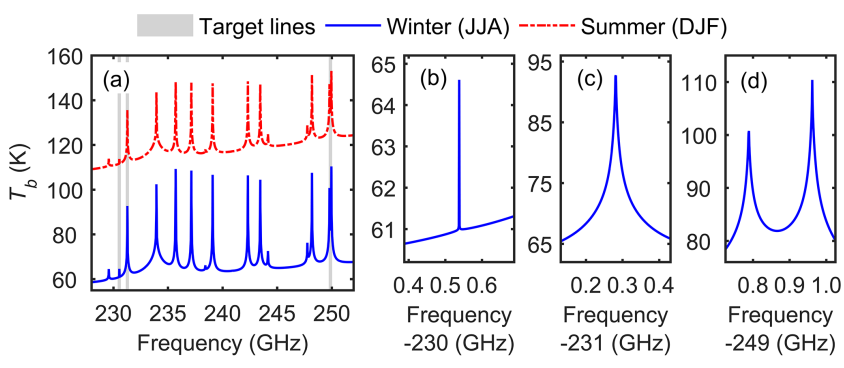

Figure 4. Simulated ground-based atmospheric brightness temperature spectra for clear-sky conditions, $60^{\circ}$ zenith angle viewing conditions at Halley station $\left(75^{\circ} 37^{\prime} \mathrm{S}, 26^{\circ} 14^{\prime} \mathrm{W}\right)$, Antarctica for (a) the frequency range $228-252 \mathrm{GHz}$ in winter (JJA, solid blue line) and summer (DJF, dashed red line). The $300 \mathrm{MHz}$ wide target frequencies, highlighted as grey shaded panels in (a), are shown enlarged for the (b) $230.54 \mathrm{GHz} \mathrm{CO}$, (c) $231.28 \mathrm{GHz} \mathrm{O}_{3}$, and (d) 249.79 and 249.96 $\mathrm{GHz} \mathrm{O}_{3}$ lines in winter.

resolution transmission (HITRAN) molecular database 2012 (Rothman et al., 2013). The oxygen continuum according to Rosenkranz (1998), nitrogen self-broadening (Liebe et al., 1993), and water vapour continuum (Rosenkranz, 1993) are included in the model. Survey clear-sky atmospheric spectra covering the 228 to $252 \mathrm{GHz}$ range, calculated on a $10 \mathrm{MHz}$ frequency grid, are shown in Fig. 5a. The higher baseline brightness temperatures, and reduced emission line signals in summer at Halley are due primarily to increased atmospheric opacity at higher tropospheric temperature and water vapour VMR. The spectra show the most intense $\mathrm{O}_{3}$ emission lines, the $J=2 \rightarrow 1 \mathrm{CO}$ line centred at $230.54 \mathrm{GHz}$, and a ${ }^{16} \mathrm{O}^{18} \mathrm{O}$ line centred at $233.95 \mathrm{GHz}$. The nearly constant mixing ratio of ${ }^{16} \mathrm{O}^{18} \mathrm{O}$ could make the $233.95 \mathrm{GHz}$ emission line suitable for profiling winds throughout the stratosphere and mesosphere. However, the Zeeman-splitting of the ${ }^{16} \mathrm{O}^{18} \mathrm{O}$ line would need to be accurately modelled in the forward model and retrieval algorithms (Navas-Guzmán et al., 2015) and such analysis is not included in this report. The enlarged $300 \mathrm{MHz}$-wide plots shown in Fig. 5b-d show 


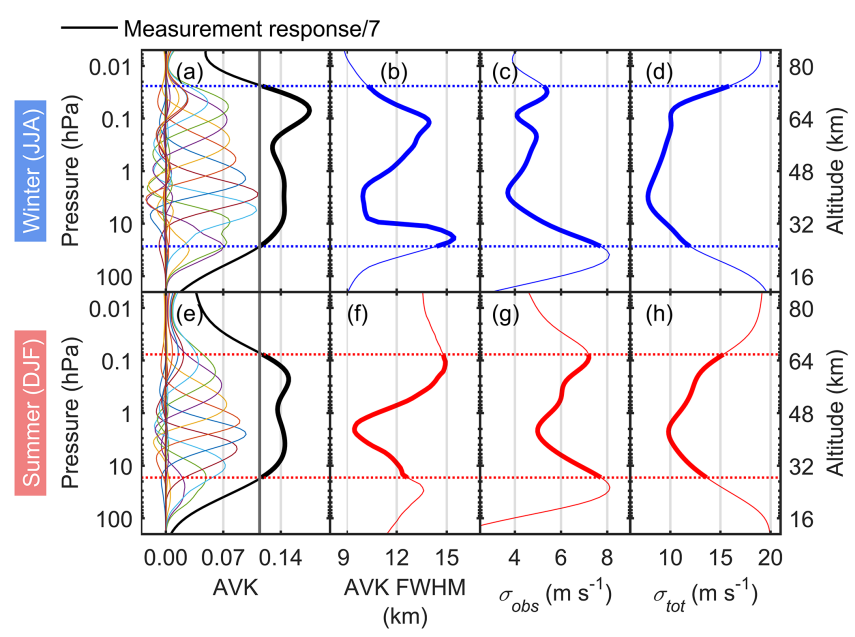

Figure 5. Example zonal wind retrievals for simulated clear-sky, $12 \mathrm{~h}$ observations (i.e. $6 \mathrm{~h}$ in east and $6 \mathrm{~h}$ in west directions) of the $\mathrm{O}_{3} 231.28 \mathrm{GHz}$ line using a ground-based radiometer with a $1400 \mathrm{~K}$ system temperature, $30 \mathrm{kHz}$ frequency resolution, and $60^{\circ}$ zenith viewing angle located at Halley station $\left(75^{\circ} 37^{\prime} \mathrm{S}, 26^{\circ} 14^{\prime} \mathrm{W}\right)$, Antarctica. In (a) and (e) every sixth averaging kernel, and the scaled measurement response (MR), are shown for mean winter (JJA) and summer (DJF) conditions respectively. The vertical grey lines in (a) and (e), dashed horizontal lines, and the thicker sections of the plots indicate where $M R \geq 0.8$.

the target frequencies for wind retrievals with the molecular line shapes dominated by contributions from Doppler- and pressure broadening.

For wind retrievals, Doppler-shifted atmospheric spectra are calculated for ground-based north- and south-, or east- and west-, pointing azimuthal directions with zonal and meridional winds at fixed values of $+20 \mathrm{~m} \mathrm{~s}^{-1}$ at all altitudes from the ground to $120 \mathrm{~km}$. The frequency spacing of the atmospheric spectra is $10 \mathrm{kHz}$ within $2.3 \mathrm{MHz}$ of line centres, $100 \mathrm{kHz}$ at $2.3-9.4 \mathrm{MHz}$ from the line centres, and $1 \mathrm{MHz}$ beyond 9.4 MHz from the line centres. This variable frequency grid ensures the spectral features are accurately represented while reducing the computing resource needed for wind retrieval calculations.

The statistical fluctuation $\Delta T(\mathrm{~K})$ in the total system temperature $T_{\text {sys }}(\mathrm{K})$ is calculated according to the ideal radiometer equation (Kraus, 1986):

$\Delta T=\frac{T_{\text {sys }}}{\sqrt{t \Delta f}}$,

where $t$ is observation time (in s) and $\Delta f$ is the frequency resolution (in $\mathrm{Hz}$ ) of the radiometer.

\subsection{Wind retrieval}

The simulated atmospheric spectra are inverted into altitude profiles of zonal and meridional wind speed using an iterative optimal estimation method (OEM) (Rodgers, 2000) implemented in the Qpack (a part of atmlab v2.2.0) software package (Eriksson et al., 2005). A detailed description of wind profile retrievals using ARTS and Qpack is given by Rüfenacht et al. (2014). Here we focus on the description of our specific retrieval setups and discussion of results for wind speed estimations from simulated $230-250 \mathrm{GHz}$ measurements at Halley, Antarctica. Iterative absorption calculations in ARTS are performed line by line inside the radiative transfer calculation, rather than using pre-calculated look-up tables, in order to accurately model atmospheric spectra at the Doppler shifted frequencies (Buehler et al., 2011).

$\mathrm{O}_{3}$ or $\mathrm{CO}$ VMR profiles and zonal/meridional wind profiles are retrieved at altitude levels $0-120 \mathrm{~km}$ with a $1 \mathrm{~km}$ spacing, where hydrostatic equilibrium is assumed for the altitude and pressure. The a priori wind speed is $0 \mathrm{~m} \mathrm{~s}^{-1}$ for all altitudes, with diagonal elements of the covariance set according to a horizontal wind speed uncertainty of $20 \mathrm{~m} \mathrm{~s}^{-1}$ based on the ECMWF reanalysis data (Fig. 3). Rüfenacht et al. (2014) showed that the retrieved wind profiles are relatively insensitive and unbiased to different a priori wind profiles even when the a priori assumption is far from the true wind. The shape of the covariance is set to decrease linearly towards the off-diagonal elements with correlation length adjusted to match the altitude resolution of initial retrievals using only the diagonal covariance matrix elements. The correlation length is typically in the range $0.6-0.8$ of a pressure decade (approximately $10-12 \mathrm{~km}$ ).

The $\mathrm{O}_{3}$ and $\mathrm{CO}$ a priori VMR profiles used in wind retrievals are those used to calculate the simulated atmospheric spectra, apart from calculations to test the effect of scaling the original VMR profiles at all altitudes by $80,90,110$, and $120 \%$. The diagonal elements in the covariance of the $\mathrm{O}_{3}$ and $\mathrm{CO}$ a priori are fixed at the square of $50 \%$ of the VMR values. The shape of the covariance is set to linearly decrease towards the off-diagonal elements with a correlation length of a fifth of a pressure decade (approximately $3 \mathrm{~km}$ ).

Nominal wind retrievals were performed for simulated clear-sky $12 \mathrm{~h}$ observations of the $\mathrm{O}_{3} 231.28 \mathrm{GHz}$ line at $60^{\circ}$ zenith angle from Halley in mean winter and summer conditions and for a radiometer with $1400 \mathrm{~K}$ system temperature and $30 \mathrm{kHz}$ frequency resolution. The averaging kernels (AVKs) for every sixth retrieved altitude are shown in Fig. 5a and e for the winter (JJA) and summer (DJF) cases respectively. The AVKs describe the relationship between the true, a priori, and retrieved atmospheric states (Rodgers, 2000). None of the AVKs peak at pressure levels above $0.02 \mathrm{hPa}$ $(\sim 74 \mathrm{~km})$ in winter, or above $0.08 \mathrm{hPa}(\sim 66 \mathrm{~km})$ in summer due to the combination of Doppler broadening dominating over pressure broadening and low $\mathrm{O}_{3}$ VMR in particular during summer when the seasonal tertiary ozone layer at 70- 
$75 \mathrm{~km}$ is not present. The lowest AVK peaks are at $27 \mathrm{hPa}$ $(\sim 25 \mathrm{~km})$ in winter and $17 \mathrm{hPa}(\sim 28 \mathrm{~km})$ in summer. The retrievals in summer are also adversely affected by higher PWV and atmospheric opacity. $\mathrm{O}_{3}$ diurnal variability also affects the measurements, with wind information retrieved from simulated observations using either day- or night-time profiles during mid-winter (15 July) but not from day-time observations at mid-summer (15 January). Wind information can be retrieved for both day- and night-time conditions at the start and end of summer (1 December and 28 February) and start and end of winter (1 June and 31 August), but for these dates day-time wind profiles only reach $\sim 64 \mathrm{~km}$ due to low $\mathrm{O}_{3}$ abundance at higher altitude.

The sum of the AVKs at each altitude, called the measurement (or total) response (MR), represents the extent to which the measurement contributes to the retrieval solution as compared to the amount of influence of the a priori at that altitude (Christensen and Eriksson, 2013). The altitude range where the retrieved wind profile has a high degree of independence from the a priori is estimated by MR values higher than 0.8 . The retrieval range is shown by the thicker sections of the black lines in Fig. 5a and e and is $0.02-27 \mathrm{hPa}(\sim 74-25 \mathrm{~km})$ for mean wintertime conditions and $0.08-17 \mathrm{hPa}(\sim 66-28 \mathrm{~km})$ in summer. Outside of these altitudes (i.e. below $25 \mathrm{~km}$ and above $74 \mathrm{~km}$ in winter, and below $28 \mathrm{~km}$ and above $66 \mathrm{~km}$ in summer) the MR weakens and wind values in these regions should be interpreted with caution as the information from the a priori becomes important. The AVKs indicate the range of altitudes over which the retrieved wind speeds has smoothed the information in the data. Thus, the full-width half-maximum (FWHM) width of the kernels provide a measure of the vertical resolution of the retrieved profile. The FWHM values shown in Fig. $5 \mathrm{~b}$ and $\mathrm{f}$ indicate altitude resolutions of $10.0-15.5$ and $9.5-14.9 \mathrm{~km}$ over the winter and summer retrieval ranges respectively, similar to the WIRA instrument performance (Rüfenacht et al., 2014). The OEM calculations provide observation errors $\left(\sigma_{\text {obs }}\right)$ and total retrieval (observation plus smoothing) errors $\left(\sigma_{\mathrm{tot}}\right)$ to give further diagnostic estimates of the uncertainty of retrieved profiles. The observation errors describe how the retrieved profiles are affected by measurement noise and are shown in Fig. 5c and g, with typical values of $4.8 \mathrm{~m} \mathrm{~s}^{-1}$ in winter and $6.1 \mathrm{~m} \mathrm{~s}^{-1}$ in summer. The observation errors are small outside of the range of the AVK peaks as the retrieval tends to the a priori values in these regions and the contribution from the measurement is small. The total retrieval errors shown in Fig. $5 \mathrm{~d}$ and $\mathrm{h}$ are in the range $7.8-15.9 \mathrm{~m} \mathrm{~s}^{-1}$ in winter and $9.8-15.3 \mathrm{~m} \mathrm{~s}^{-1}$ in summer, and outside the range of AVK peaks tend towards the a priori standard deviation of $20 \mathrm{~m} \mathrm{~s}^{-1}$.

We have also assessed measurement uncertainties using Monte Carlo simulations, as was done by Rüfenacht et al. (2014) in their wind retrievals using the $\mathrm{O}_{3} 142.18 \mathrm{GHz}$ emission line. Our Monte Carlo error analysis results, using 500 repeat zonal wind retrievals to test the retrieval al- gorithm's ability to reproduce the "true" state of the atmosphere, are shown in Fig. 6. Figure $6 \mathrm{c}$ and $\mathrm{h}$ are for the winter and summer nominal cases, i.e. simulated clear-sky, $12 \mathrm{~h}$ observations (i.e. $6 \mathrm{~h}$ in east and $6 \mathrm{~h}$ in west directions) of the $\mathrm{O}_{3} 231.28 \mathrm{GHz}$ line using a ground-based radiometer with a $1400 \mathrm{~K}$ system temperature, $30 \mathrm{kHz}$ frequency resolution, and $60^{\circ}$ zenith viewing angle. Over the trustable altitude range the mean wind profile is $20.3 \mathrm{~m} \mathrm{~s}^{-1}$ in winter and $19.6 \mathrm{~m} \mathrm{~s}^{-1}$ in summer, both values within $2 \%$ of the "true" value of $20.0 \mathrm{~m} \mathrm{~s}^{-1}$. The standard deviation of the individual retrievals is an estimator for the uncertainty of the wind retrieval, and the mean values of $4.8 \mathrm{~m} \mathrm{~s}^{-1}$ in winter and $6.1 \mathrm{~m} \mathrm{~s}^{-1}$ in summer match the mean observation errors determined from single retrievals. This is not surprising as both parameters are dependent on the signal-to-noise ratio of the input spectrum. Our calculated observation error is considerably smaller than the $12-20 \mathrm{~m} \mathrm{~s}^{-1}$ range reported for the WIRA new single sideband receiver (Rüfenacht et al., 2014). The improvement is probably largely due to the low noise levels for a SIS mixer receiver used in our spectrum simulations, and the larger Doppler shifts and higher line intensity of $\mathrm{O}_{3}$ at $231.28 \mathrm{GHz}$ compared to the $142.18 \mathrm{GHz}$ line. However it should be noted that the location and atmospheric conditions for the calculations differ and an exact comparison between the actual, or likely, performance of each instrument cannot be made using these data. Figure $6 \mathrm{a}-\mathrm{b}, \mathrm{d}-$ e and $\mathrm{f}-\mathrm{g}, \mathrm{i}-\mathrm{j}$ show the Monte Carlo simulation results for winter and summer conditions respectively when the a priori $\mathrm{O}_{3}$ VMR profiles are scaled by $80,90,110$, and $120 \%$ of the "true" profiles used to simulate the atmospheric spectra. These calculations indicate that 10 and $20 \%$ uncertainties in a priori $\mathrm{O}_{3}$ VMR could introduce errors in the retrieved wind profiles of \pm 2 and $\pm 4 \mathrm{~m} \mathrm{~s}^{-1}$, respectively. However, careful construction of a priori datasets and configuring of retrieval parameters may mitigate against such errors which would be significant at wind speeds of $20 \mathrm{~m} \mathrm{~s}^{-1}$ but would have less effect on measuring wind speeds of $100 \mathrm{~m} \mathrm{~s}^{-1}$. Uncertainties in spectroscopic parameters and temperature profiles are not expected to cause significant biases in the retrieved winds, as was reported by Rüfenacht et al. (2014).

\section{Results}

In the following sections horizontal wind retrieval results are presented for simulated scenarios where five instrument parameters are varied: the zenith viewing angle of the groundbased observation, the instrument's frequency resolution, the radiometer system temperature, the observed emission line, and the measurement time. The main results are summarised in Table 1. The wind retrievals shown are for the zonal component of the horizontal wind and quoted measurement times are for corresponding observations made in opposing east and west directions. Identical results are obtained for merid- 


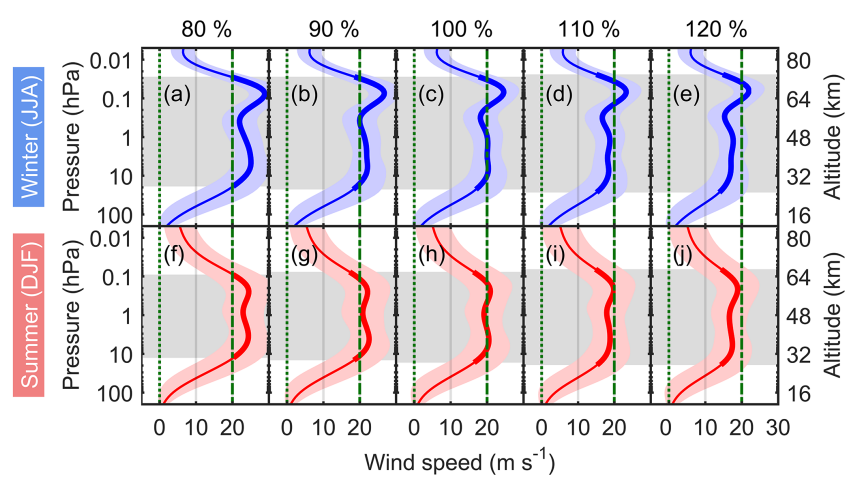

Figure 6. Monte Carlo error analyses using 500 repeat zonal wind retrievals for simulated clear-sky, $12 \mathrm{~h}$ observations (i.e. $6 \mathrm{~h}$ in east and $6 \mathrm{~h}$ in west directions) of the $\mathrm{O}_{3} 231.28 \mathrm{GHz}$ line using a ground-based radiometer with a $1400 \mathrm{~K}$ system temperature, $30 \mathrm{kHz}$ frequency resolution, and $60^{\circ}$ zenith viewing angle located at Halley station $\left(75^{\circ} 37^{\prime} \mathrm{S}, 26^{\circ} 14^{\prime} \mathrm{W}\right)$, Antarctica. The a priori $\mathrm{O}_{3} \mathrm{VMR}$ profiles are scaled by $80,90,100,110$, and $120 \%$ of the "true" profiles for (a)-(e), and (f)-(j) respectively. The mean retrieved winter and summer winds and $1 \sigma$ errors (shaded areas) are shown, with the thicker sections and the shaded grey panels indicating where $\mathrm{MR} \geq 0.8$. The true wind profile used to simulate the atmospheric spectra is shown by the dash-dotted green lines. The a priori wind profile is shown by the dotted green lines.

ional wind analyses where the simulated measurements are in north and south pointing directions.

\subsection{Effect of zenith angle}

In order to observe a Doppler shift in the millimetre-wave atmospheric emission arising from the horizontal motion of the molecules in the air mass, observations must be made at non-zero zenith angles. The results of wind retrievals for simulated observations with zenith angles of 45,60 , and $80^{\circ}$ are shown in Fig. 7 and in Table 1. A zenith angle of $80^{\circ}$ gives the best results for the Halley mean wintertime conditions considered, with winds retrieved over $0.02-38.8 \mathrm{hPa}(\sim 74$ $23 \mathrm{~km}$ ). Summertime coverage at $80^{\circ}$ is over a narrower pressure range, $0.12-16.9 \mathrm{hPa}(\sim 63-28 \mathrm{~km})$, and at a $60^{\circ}$ angle the retrieval for summer conditions reaches slightly higher, covering $0.08-16.9 \mathrm{hPa}(\sim 66-28 \mathrm{~km})$. The $80^{\circ}$ observations give the best height resolutions in winter, estimated at 9$15 \mathrm{~km}$ from the AVK FWHMs, and smallest observation errors, in the range $3.3-7.2 \mathrm{~m} \mathrm{~s}^{-1}$. In summer both the height resolutions and observation errors at $60^{\circ}$ are slightly smaller than for the corresponding 45 or $80^{\circ}$ summer retrievals over most of the altitudes where wind information is retrieved from the measurement. With $30^{\circ}$ zenith angle simulations the retrieval total response did not exceed 0.8 at any altitude. The seasonal variability of the wind retrieval quality indicates that the wind information contained in the Doppler-shifted $\mathrm{O}_{3}$ 231.28 GHz emission line signals depends on zenith angledependent factors including line-of-sight Doppler shifts, air

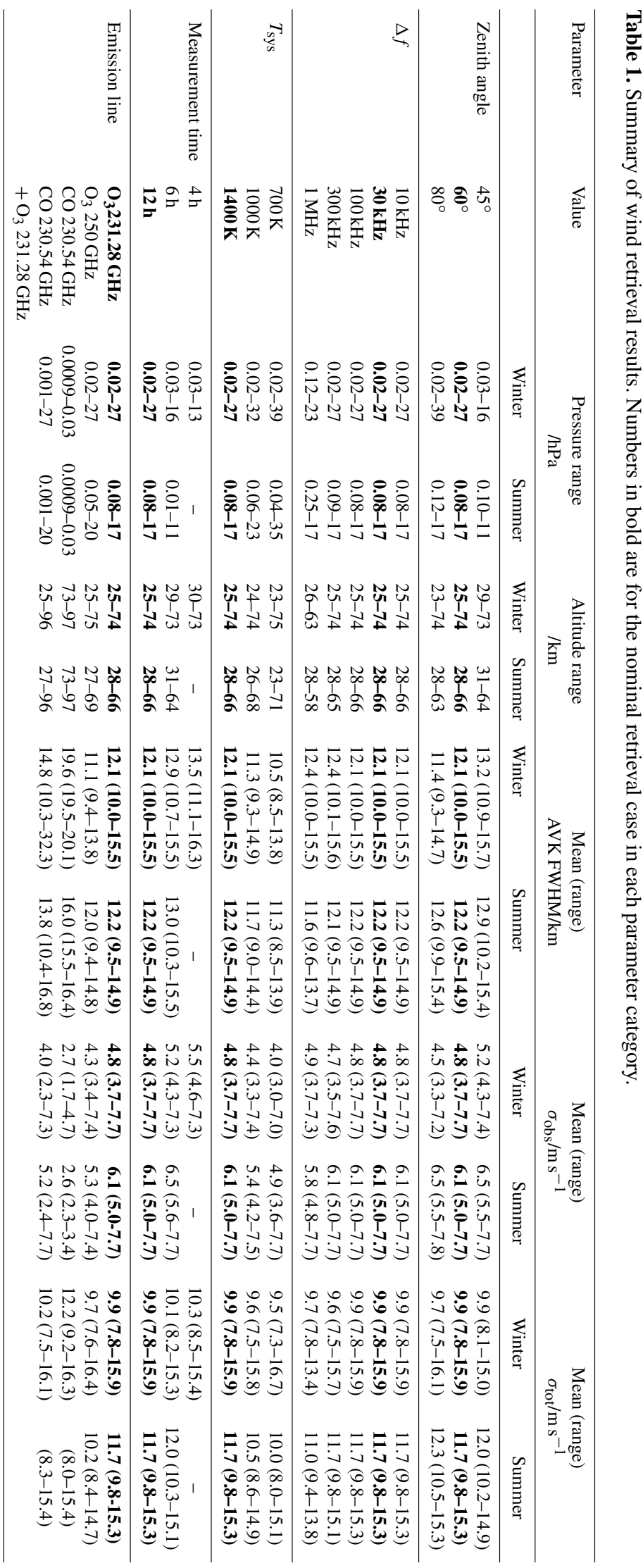




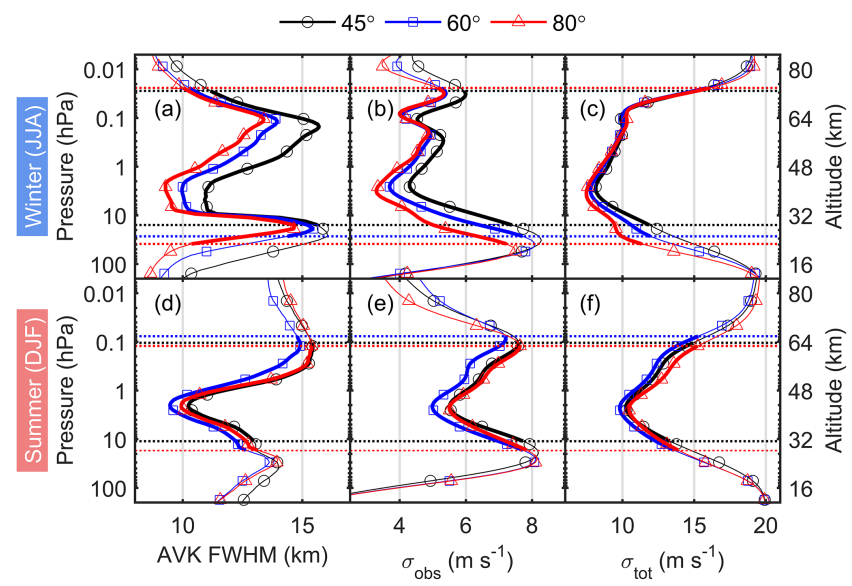

Figure 7. Zonal wind retrievals for different zenith viewing angles, where AVK FWHM are the full-width half-maxima of each averaging kernel, $\sigma_{\mathrm{obs}}$ is the measurement uncertainty, and $\sigma_{\text {tot }}$ is the total uncertainty. Calculations are for simulated clear-sky, $12 \mathrm{~h}$ observations (i.e. $6 \mathrm{~h}$ in east and $6 \mathrm{~h}$ in west directions) of the $\mathrm{O}_{3}$ $231.28 \mathrm{GHz}$ line in mean winter (JJA) and summer (DJF) conditions at Halley station $\left(75^{\circ} 37^{\prime} \mathrm{S}, 26^{\circ} 14^{\prime} \mathrm{W}\right)$, Antarctica using a groundbased radiometer with a $1400 \mathrm{~K}$ system temperature and $30 \mathrm{kHz}$ frequency resolution. The horizontal dashed lines and thicker sections of the curves indicate the pressure/altitude ranges where $\mathrm{MR} \geq 0.8$.

mass factor, and atmospheric opacity as well as the effects of different seasonal $\mathrm{O}_{3}$ VMR and temperature profiles. For the zenith angles considered, $80^{\circ}$ provides the highest air mass factor and highest LOS Doppler shift with a relatively small $10^{\circ}$ angle between the observing beam and the horizontal plane giving high projection efficiency. The optimum zenith angle will vary with ground-based location and the atmospheric conditions at the time of making observations, as well as considerations of the spatial distances between measurements in opposite directions. From a practical perspective, the range of zenith angles that the instrument can be pointed may be limited by the requirement to have a clear, unobscured view of the sky continuously throughout measurements in each different azimuthal direction.

\subsection{Effect of instrument frequency resolution}

The results of wind retrievals for simulated observations with instrument channel spacing of $10,30,100,300 \mathrm{kHz}$, and $1 \mathrm{MHz}$ are shown in Fig. 8 and Table 1. Increasing the frequency resolution from $10 \mathrm{kHz}$ to $300 \mathrm{kHz}$ has little effect on horizontal wind retrievals from $12 \mathrm{~h}$ simulated observations of the $231.28 \mathrm{GHz} \mathrm{O}$ emission line in mean wintertime or summertime conditions at Halley. Height resolutions, estimated from the AVK FWHMs, and observation errors are similar for all five resolutions below $1 \mathrm{hPa}(\sim 48 \mathrm{~km})$. At $1 \mathrm{MHz}$ resolution the upper limit where the measured data dominate the wind retrieval is substantially lower, at $0.12 \mathrm{hPa}$ $(\sim 63 \mathrm{~km})$ in winter and $0.25 \mathrm{hPa}(\sim 58 \mathrm{~km})$ in summer and,

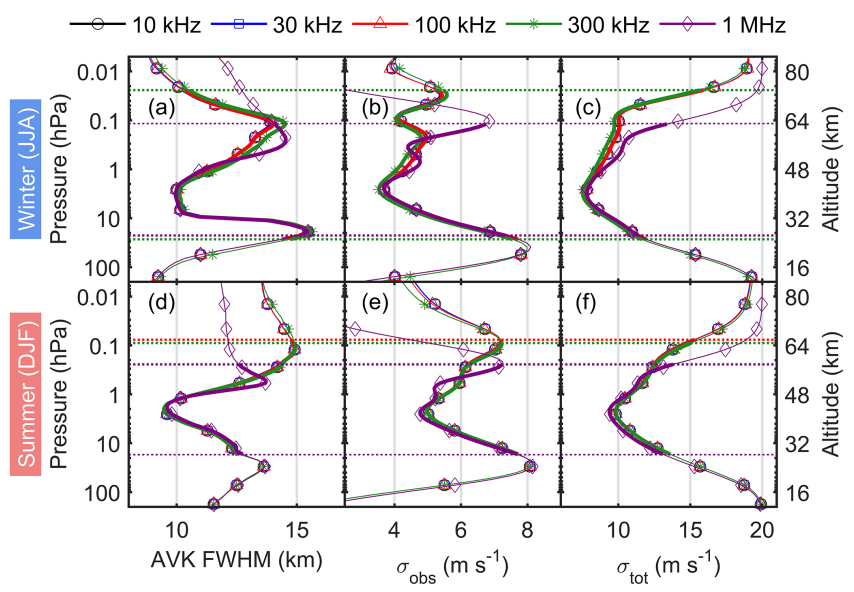

Figure 8. As Fig. 7, but for different frequency resolutions and a $60^{\circ}$ zenith viewing angle.

close to this altitude limit, the observation errors increase to $7.7 \mathrm{~m} \mathrm{~s}^{-1}$.

The lack of sensitivity of the simulated wind retrievals to frequency resolution, at least up to $300 \mathrm{kHz}$ channel spacing, is surprising given that the LOS Doppler shift of the $\mathrm{O}_{3} 231.28 \mathrm{GHz}$ emission line is $13.4 \mathrm{kHz}$ for a $20 \mathrm{~m} \mathrm{~s}^{-1}$ horizontal wind viewed at $60^{\circ}$ zenith angle. However, the Jacobian and gain matrices for the wind retrievals indicate the Doppler-shifted spectral response should be adequately sampled at instrument resolutions up to $300 \mathrm{kHz}$ for altitudes where the $\mathrm{O}_{3}$ measurement contributes significantly to the retrieval. Frequency resolution in the range $10-30 \mathrm{kHz}$ is needed to determine upper mesospheric winds from CO $230.54 \mathrm{MHz}$ observations where Doppler shifts above $75 \mathrm{~km}$ result in changes to the spectral distribution much closer to the emission line centre. The values of the Jacobian describing the $\mathrm{O}_{3}$ wind retrieval, normalised by the layer thickness of the retrieval grid for observations at a $60^{\circ}$ zenith angle, are shown in Fig. 9 with typical values around $0.15 \mathrm{mK}\left(\mathrm{m} \mathrm{s}^{-1}\right)^{-1} \mathrm{~km}^{-1}$. The effect of wind variations of $20 \mathrm{~m} \mathrm{~s}^{-1}$ on the measured atmospheric brightness temperature will therefore be small, of the order of $3 \mathrm{mK} \mathrm{km}^{-1}$. For an ideal instrument the baseline signal-to-noise ratio varies as $1 / \sqrt{\Delta f}$ for a fixed measurement time, i.e. a factor 3.3 improvement for a 10 -fold change in frequency resolution $(\Delta f)$ from 30 to $300 \mathrm{kHz}$. Although the improvement in the signal-to-noise ratio gained by lower resolution measurements is desirable for measuring small changes in brightness temperature arising from the Doppler shifts, this appears to be largely offset by reduced sampling of the frequency distribution of the emission signal. Lower resolution measurements would however produce smaller datasets for a given frequency bandwidth, which would have the advantages of processing speed and lower demand on computing resources for data storage, transfer, and analysis to retrieve atmospheric information. 


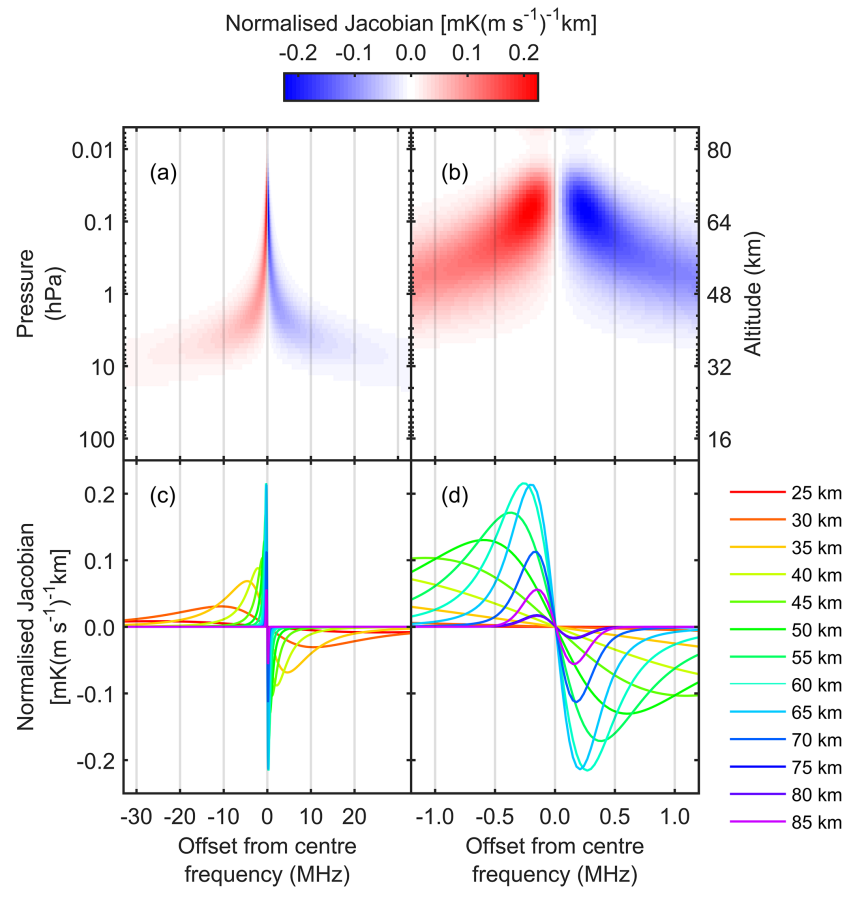

Figure 9. Rows of the Jacobian describing the horizontal wind retrieval, normalised by the layer thickness of the retrieval grid. The data are from zonal wind retrievals for simulated clear-sky, $12 \mathrm{~h}$ observations (i.e. $6 \mathrm{~h}$ in east and $6 \mathrm{~h}$ in west directions) of the $\mathrm{O}_{3} 231.28 \mathrm{GHz}$ line using a ground-based radiometer with a $1400 \mathrm{~K}$ system temperature, $30 \mathrm{kHz}$ frequency resolution, and $60^{\circ}$ zenith viewing angle located at Halley station $\left(75^{\circ} 37^{\prime} \mathrm{S}, 26^{\circ} 14^{\prime} \mathrm{W}\right)$, Antarctica. The colour scale in (a) and (b) indicates the values of the Jacobian matrix. Rows of the Jacobian matrix for selected altitude levels are plotted in (c) and (d). Plots (b) and (d) show the centre frequencies on an expanded scale.

\subsection{Effect of radiometer system temperature and measurement time}

The results of zonal wind retrievals for simulated observations with radiometer system temperatures of 700, 1000, and $1400 \mathrm{~K}$ are shown in Fig. 10 and Table 1. The altitude range, height resolution, and observation errors of the wind retrievals all improve with lower system temperature, due to the higher signal-to-noise ratio of the measurements. The signal-to-noise ratio of the simulated measurements is based on real instrument data for a radiometer operating at 230 $250 \mathrm{GHz}$ and varies with $T_{\text {sys }}$, i.e. the noise level halving when $T_{\text {sys }}$ changes from 1400 to $700 \mathrm{~K}$. This impacts directly on the measurement of small changes in atmospheric emission spectra arising from Doppler shift perturbations and the retrieval of wind information, as discussed previously in Sect. 3.2.

The results of zonal wind retrievals for simulated 4,6 , and $12 \mathrm{~h}$ measurements (i.e. 2, 4, and $6 \mathrm{~h}$ observations in east and west directions) with a system temperature of $1400 \mathrm{~K}$

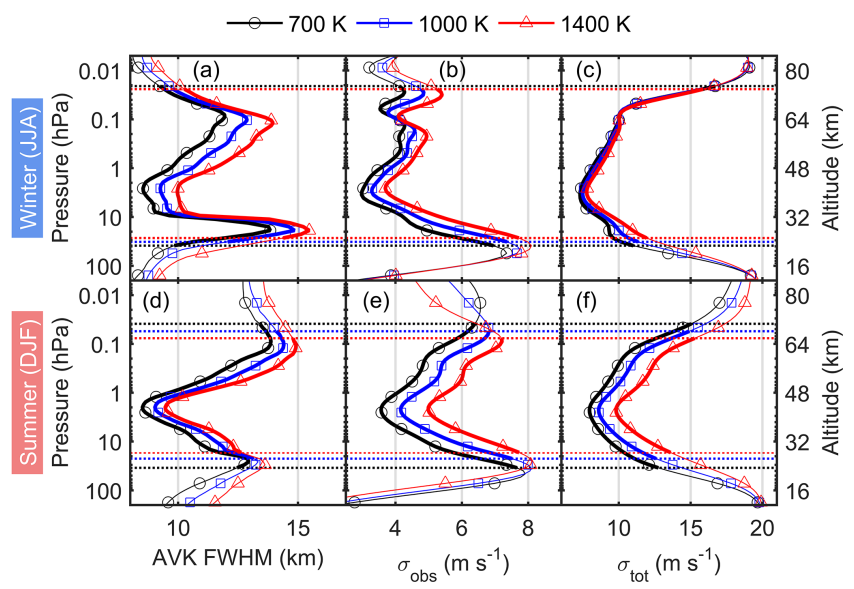

Figure 10. As Fig. 7, but for different radiometer system temperatures and a $60^{\circ}$ zenith viewing angle.

are shown in Fig. 11 and Table 1. For the $4 \mathrm{~h}$ summertime observation, and measurement times below $4 \mathrm{~h}$ (not shown) for the winter case, the retrieval total response does not exceed 0.8 at any altitude. The minimum measurement times for successfully retrieving zonal or meridional winds is $4 \mathrm{~h}$ in mean wintertime conditions at Halley and $6 \mathrm{~h}$ in summer for the specified instrument configuration. The altitude range, height resolution, and observation error of the wind retrievals all improve as measurement time $t$ increases, due to higher signal-to-noise ratio, which varies as $\sqrt{t}$. The time resolution of horizontal wind measurements is limited by the need to acquire atmospheric spectra with sufficiently low noise for the wind retrieval to succeed. During optimum observing conditions at Halley the measurement time is considerably reduced, as shown in Fig. 12 and Table 1 for mean wintertime atmospheric profiles when PWV is in the lower quartile, i.e. during a quarter of winter (JJA) conditions at Halley when PWV is below $0.92 \mathrm{~mm}$, which corresponds to 23 days per year. A minimum measurement time of $1.5 \mathrm{~h}$ is achieved using a $1400 \mathrm{~K}$ system temperature radiometer, reducing to $0.5 \mathrm{~h}$ resolution for a $700 \mathrm{~K}$ radiometer. At lower measurement times the trade-off is a modest reduction in altitude coverage and resolution, and increased observation error.

\subsection{Choice of emission line(s)}

The results of zonal wind retrievals for simulated $12 \mathrm{~h}$ measurements of the $\mathrm{O}_{3} 231.28 \mathrm{GHz}, \mathrm{O}_{3} 250 \mathrm{GHz}, \mathrm{CO}$ $230.54 \mathrm{GHz}$, and combined $\mathrm{CO} 230.54 \mathrm{GHz}$ and $\mathrm{O}_{3}$ $231.28 \mathrm{GHz}$ emission lines, with a radiometer system temperature of $1400 \mathrm{~K}$ and $60^{\circ}$ zenith viewing angle are shown in Fig. 13 and Table 1. Using either the single $231.28 \mathrm{GHz}$ $\mathrm{O}_{3}$ line or the pair of blended $\mathrm{O}_{3}$ lines centred at 249.79 and $249.96 \mathrm{GHz}$ (see Fig. 4) the altitude range, height resolution, and observation errors of the retrievals are very similar for mean wintertime conditions. However in summer the 


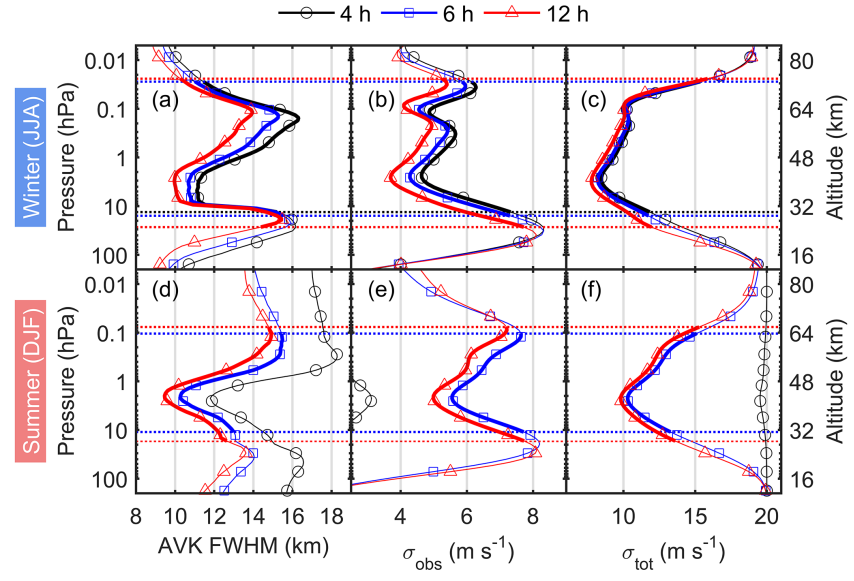

Figure 11. As Fig. 7, but for different total measurement times and a $60^{\circ}$ zenith viewing angle.

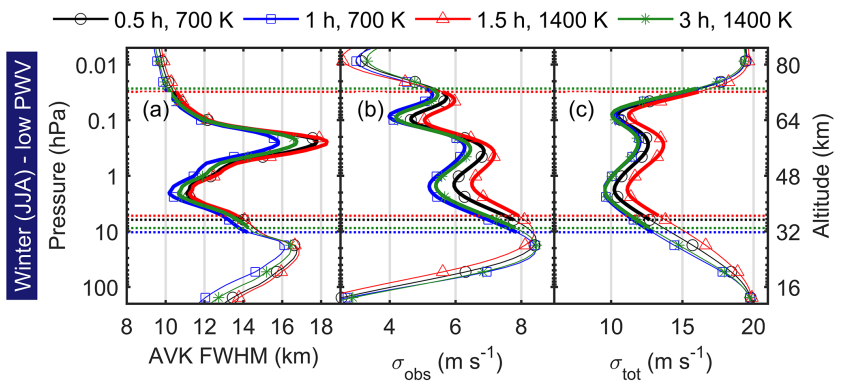

Figure 12. As Fig. 11, but simulated for different total measurement times and radiometer system temperatures and under optimal wintertime observing conditions at Halley where precipitable water vapour (PWV) is in the lower quartile (below $0.92 \mathrm{~mm}$ ).

retrieval using the pair of blended lines covers higher altitudes, reaching $0.05 \mathrm{hPa}(\sim 69 \mathrm{~km})$ with smaller observation and total retrieval errors.

The retrieval using the $\mathrm{CO} 230.54 \mathrm{GHz}$ emission line yields wind information over $0.0009-0.03 \mathrm{hPa}(\sim 97-73 \mathrm{~km})$ in both summer and winter conditions. The retrieval altitudes correspond to the higher $\mathrm{CO}$ mixing ratios in the upper mesosphere and lower thermosphere $(75-100 \mathrm{~km})$ where $\mathrm{CO}$ is mainly produced by ultraviolet photo-dissociation of carbon dioxide $\left(\mathrm{CO}_{2}\right)$. At the retrieval altitudes the $\mathrm{CO}$ linewidth is dominated by Doppler (thermal) broadening. However the Doppler FWHM linewidth is at a minimum with a reasonably constant value of $440 \pm 10 \mathrm{MHz}$ between 70 and $97 \mathrm{~km}$. Doppler broadening increases above $97 \mathrm{~km}$ due to higher temperatures in the lower thermosphere. Pressure broadening dominates, and the $\mathrm{CO}$ linewidth rapidly increases, below $62 \mathrm{~km}$ in winter and below $69 \mathrm{~km}$ in summer. Thus the wind retrieval is possible at high altitudes where the minimum in the Doppler broadening characterises the altitude and where the $\mathrm{CO}$ mixing ratio is sufficiently high, but the height resolution of the retrieval is limited by the uniformity of the

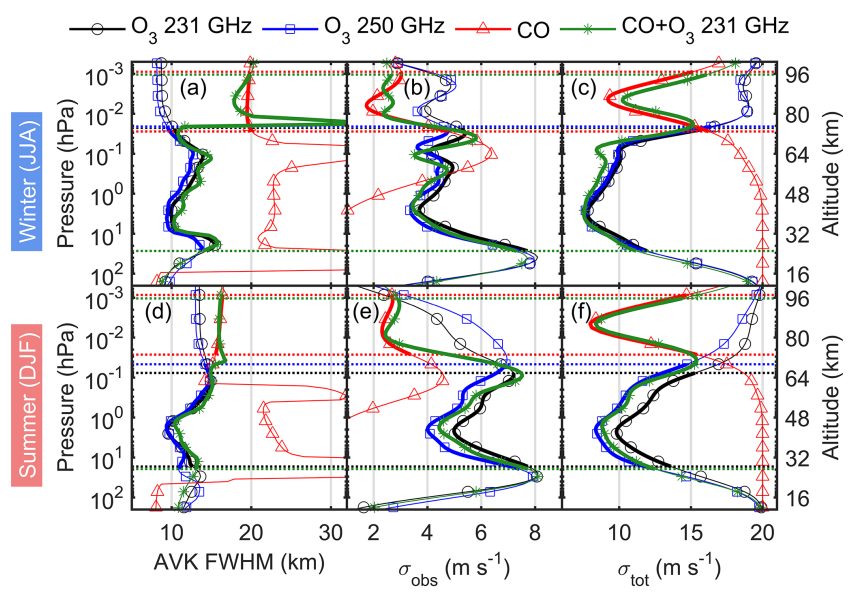

Figure 13. As Fig. 7, but for retrievals using the $\mathrm{O}_{3} 231.28 \mathrm{GHz}$, $\mathrm{O}_{3} 250 \mathrm{GHz}, \mathrm{CO} 230.54 \mathrm{GHz}$, and combined $\mathrm{CO} 230.54 \mathrm{GHz}$ and $\mathrm{O}_{3} 231.28 \mathrm{GHz}$ atmospheric lines and a $60^{\circ}$ zenith viewing angle.

Doppler linewidth. At lower altitudes where $\mathrm{CO}$ mixing ratios are low, due primarily to the oxidation reaction with hydroxyl (OH) to form $\mathrm{CO}_{2}$ (Minschwaner et al., 2010), the MR is below 0.8 and wind values in these regions should be interpreted with caution as the information from the a priori becomes important. The $\mathrm{CO}$ wind retrieval corresponds to an altitude of $85 \pm 12 \mathrm{~km}$ where $\mathrm{O}_{3}$ analysis alone does not reliably retrieve wind information. The height resolutions, estimated at $\sim 20 \mathrm{~km}$ in winter and $\sim 16 \mathrm{~km}$ in summer from the AVK FWHMs, are coarser than for the $\mathrm{O}_{3}$ wind retrievals whereas the observation errors are smaller at $\sim 3 \mathrm{~m} \mathrm{~s}^{-1}$ in both winter and summer conditions at Halley. Our simulated wind retrieval is comparable to the polar mesospheric wind speeds above the South Pole determined with uncertainty $\pm 5 \mathrm{~m} \mathrm{~s}^{-1}$ by observing the $\mathrm{CO}$ line at $461 \mathrm{GHz}$ (Burrows et al., 2007).

Wind retrievals using the combined $\mathrm{CO} 230.54 \mathrm{GHz}$ and $\mathrm{O}_{3} 231.28 \mathrm{GHz}$ observations provide the broadest coverage, $0.001-27 \mathrm{hPa}(\sim 96-25 \mathrm{~km})$ in winter and $0.001-20 \mathrm{hPa}$ $(\sim 96-27 \mathrm{~km})$ in summer. Over this range the height resolutions, observation errors, and total errors are similar to those for the separate $\mathrm{CO} 230.54 \mathrm{GHz}$ and $\mathrm{O}_{3} 231.28 \mathrm{GHz}$ retrievals, apart from at the overlapping altitudes $(\sim 75-80 \mathrm{~km})$ in winter where the AVK FWHMs are as high as $32 \mathrm{~km}$. Fine tuning the OEM wind retrieval for the combined analysis may optimise the information retrieval from the two emission lines and eliminate this artefact in the upper mesospheric data. 


\section{Conclusions}

The proof-of-concept simulations demonstrate that polar middle atmosphere winds could be profiled with $\sim 5 \mathrm{~m} \mathrm{~s}^{-1}$ measurement uncertainty and $\sim 12 \mathrm{~km}$ altitude resolution using ground-based passive millimetre-wave measurements of Doppler-shifted $\mathrm{O}_{3}$ emission lines in the $230-250 \mathrm{GHz}$ region and OEM retrieval. The effects of clear-sky seasonal mean winter/summer conditions, zenith angle of the received atmospheric emission, and spectrometer frequency resolution on the altitude coverage, measurement uncertainty, and height and time resolution of the retrieved wind profiles have been determined. We have used simulations of atmospheric spectra from Halley station, Antarctica as a test case. For a SIS-mixer-based receiver, the minimum observation times for determining zonal or meridional wind profiles would be $0.5-1.5 \mathrm{~h}$ during optimal wintertime conditions, and more typically $\sim 4 \mathrm{~h}$ in winter and $\sim 6 \mathrm{~h}$ during summer. The millimetre-wave radiometry technique would allow stratospheric and mesospheric wind observations covering the altitude range $25-74 \mathrm{~km}$ in winter and $28-66 \mathrm{~km}$ in summer, with extension up to $\sim 96 \mathrm{~km}$ by also observing the $\mathrm{CO}$ $230.54 \mathrm{GHz}$ emission line. Such observations would complement established radiosonde and radar techniques that provide data on wind speeds in the troposphere and upper mesosphere. This would allow more detailed investigations of important dynamical and chemical transport processes associated with large-scale planetary wave activity and atmospheric tides that perturb the mean circulation patterns. A next stage would be to upgrade an existing $230-250 \mathrm{GHz}$ radiometer, modifying the sky-viewing mirror at the front-end of the receiver to make automated observations at different azimuthal and zenith directions, and performing atmospheric measurements and retrievals to characterise the instrument performance and wind measurement capability under different conditions in the field.

Acknowledgements. This work has been supported by the UKs Natural Environment Research Council (NERC) Technologies Proof-of-Concept grant reference NE/L012197/1 awarded to D. A. Newnham, T. Moffat-Griffin, and H. C. Pumphrey. We acknowledge ECMWF for the re-analysis data. The authors thank the ARTS and Qpack development teams and P. Eriksson at Chalmers University of Technology and P. Kirsch at BAS for assistance configuring and running the code, E. C. Turner at BAS for processing ERA data, D. Marsh at the National Center for Atmospheric Research (NCAR) for providing SD-WACCM data, and N. Kämpfer, R. Rüfenacht, and A. Murk at the University of Bern and N. J. Mitchell at the University of Bath for helpful discussions.

Edited by: M. Rapp

Reviewed by: two anonymous referees

\section{References}

Alcaydé, D. and Fontanari, J.: Neutral temperature and winds from EISCAT CP-3 observations, J. Atmos. Terr. Phys., 48, 931-947, doi:10.1016/0021-9169(86)90067-X, 1986.

Assink, J. D., Waxler, R., and Drob, D.: On the sensitivity of infrasonic traveltimes in the equatorial region to the atmospheric tides, J. Geophys. Res., 117, D01110, doi:10.1029/2011JD016107, 2012.

Assink, J. D., Waxler R., Frazier, W. G., and Lonzaga, J.: The estimation of upper atmospheric wind model updates from infrasound data, J. Geophys. Res.-Atmos., 118, 10707-10724, doi:10.1002/jgrd.50833, 2013.

Baron, P., Murtagh, D. P., Urban, J., Sagawa, H., Ochiai, S., Kasai, Y., Kikuchi, K., Khosrawi, F., Körnich, H., Mizobuchi, S., Sagi, K., and Yasui, M.: Observation of horizontal winds in the middle-atmosphere between $30^{\circ} \mathrm{S}$ and $55^{\circ} \mathrm{N}$ during the northern winter 2009-2010, Atmos. Chem. Phys., 13, 6049-6064, doi:10.5194/acp-13-6049-2013, 2013.

Baumgarten, G.: Doppler Rayleigh/Mie/Raman lidar for wind and temperature measurements in the middle atmosphere up to 80 km, Atmos. Meas. Tech., 3, 1509-1518, doi:10.5194/amt-31509-2010, 2010.

Brasseur, G. P. and Solomon, S.: Aeronomy of the Middle Atmosphere: Chemistry and Physics of the Stratosphere and Mesosphere, Springer, Dordrecht, the Netherlands, ISBN-13: 978-14020-3284, 2005.

Briggs, B. H.: Radar observations of atmospheric winds and turbulence: a comparison of techniques, J. Atmos. Terr. Phys., 42, 823-833, doi:10.1016/0021-9169(80)90086-0, 1980.

Buehler, S. A., Eriksson, P., Kuhn, T., von Engeln, A., and Verdes, C.: ARTS, the Atmospheric Radiative Transfer Simulator, J. Quant. Spectrosc. Ra., 91, 65-93, doi:10.1016/j.jqsrt.2004.05.051, 2005.

Buehler, S. A., Eriksson, P., and Lemke, O.: Absorption lookup tables in the radiative transfer model ARTS, J. Quant. Spectrosc. Ra., 112, 1559-1567, doi:10.1016/j.jqsrt.2011.03.008, 2011.

Burrage, M. D., Skinner, W. R., Gell, D. A., Hays, P. B., Marshall, A. R., Ortland, D. A., Manson, A. H., Franke, S. J., Fritts, D. C., Hoffman, P., McLandress, C., Niciejewski, R., Schmidlin, F. J., Shepherd, G. G., Singer, W., Tsuda, T., and Vincent, R. A.: Validation of mesosphere and lower thermosphere winds from the high resolution Doppler imager on UARS, J. Geophys. Res., 101, 10365-10392, doi:10.1029/95JD01700, 1996.

Burrows, S. M., Martin, C. L., and Roberts, E. A.: Highlatitude remote sensing of mesospheric wind speeds and carbon monoxide, J. Geophys. Res. Atmos., 112, D17109, doi:10.1029/2006JD007993, 2007.

Christensen, O. M. and Eriksson, P.: Time series inversion of spectra from ground-based radiometers, Atmos. Meas. Tech., 6, 15971609, doi:10.5194/amt-6-1597-2013, 2013.

Chu, Y. H., Su, C. L., Larsen, M. F., and Chao, C. K.: First measurements of neutral wind and turbulence in the mesosphere and lower thermosphere over Taiwan with a chemical release experiment, J. Geophys. Res.-Space, 112, A02301, doi:10.1029/2005JA011560, 2007.

Chunchuzov, I., Kulichkov, S., Perepelkin, V., Popov, O., Firstov, P., Assink, J., and Marchetti, E.: Study of the wind velocity-layered structure in the stratosphere, mesosphere and lower thermosphere by using infrasound probing 
of the atmosphere, J. Geophys. Res.-Atmos., 120, 8828-8840, doi:10.1002/2015JD023276, 2015.

Clancy, R. T. and Muhleman, D. O.: Groundbased Microwave Spectroscopy of the Earth's Stratosphere and Mesosphere, in: Atmospheric Remote Sensing by Microwave Radiometry, edited by: Janssen, M. A., ISBN-10: 0471628913, ISBN-13: 9780471628910, Wiley-Blackwell, 1993.

Daae, M., Straub, C., Espy, P. J., and Newnham, D. A.: Atmospheric ozone above Troll station, Antarctica observed by a ground based microwave radiometer, Earth Syst. Sci. Data, 6, 105-115, doi:10.5194/essd-6-105-2014, 2014

Dee, D. P., Uppala, S. M., Simmons, A. J., Berrisford, P., Poli, P., Kobayashi, S., Andrae, U., Balmaseda, M. A., Balsamo, G., Bauer, P., Bechtold, P., Beljaars, A. C. M., van de Berg, L., Bidlot, J., Bormann, N., Delsol, C., Dragani, R., Fuentes, M., Geer, A. J., Haimberger, L., Healy, S. B., Hersbach, H., Hólm, E. V., Isaksen, L., Kållberg, P., Köhler, M., Matricardi, M., McNally, A. P., Monge-Sanz, B. M., Morcrette, J.-J., Park, B.-K., Peubey, C., de Rosnay, P., Tavolato, C., Thépaut, J.-N., and Vitart, F.: The ERA-Interim reanalysis: configuration and performance of the data assimilation system, Q. J. Roy. Meteor. Soc., 137, 553-597, doi:10.1002/qj.828, 2011.

Drob, D. P., Emmert, J. T., Crowley, G., Picone, J. M., Shepherd, G. G., Skinner, W., Hays, P., Niciejewski, R. J., Larsen, M., She, C. Y., Meriwether, J. W., Hernandez, G., Jarvis, M. J., Sipler, D. P., Tepley, C. A., O'Brien, M. S., Bowman, J. R., Wu, Q., Murayama, Y., Kawamura, S., Reid, I. M., and Vincent, R. A.: An empirical model of the Earth's horizontal wind fields: HWM07, J. Geophys. Res.-Spaces, 113, A12304, doi:10.1029/2008JA013668, 2008.

Drob, D. P., Emmert, J. T., Meriwether, J. W., Makela, J. J., Doornbos, E., Conde, M., Hernandez, G., Noto, J., Zawdie, K. A., McDonald, S. E., Huba, J. D., and Klenzing, J. H.: An update to the Horizontal Wind Model (HWM): The quiet time thermosphere, Earth and Space Science, 2, 301-319, doi:10.1002/2014EA000089, 2015.

Eriksson, P., Jiménez, C., and Buehler, S. A.: Qpack, a general tool for instrument simulation and retrieval work, J. Quant. Spectrosc. Ra., 91, 47-64, doi:10.1016/j.jqsrt.2004.05.050, 2005.

Eriksson, P., Buehler, S. A., Davis, C. P., Emde, C., and Lemke, O.: ARTS, the atmospheric radiative transfer simulator, version 2, J. Quant. Spectrosc. Ra., 112, 1551-1558, doi:10.1016/j.jqst.2011.03.001, 2011.

Espy, P., Hartogh, P., and Holmén, K.: A microwave radiometer for the remote sensing of nitric oxide and ozone in the middle atmosphere, in: Remote Sensing of Clouds and the Atmosphere XI, Proc. SPIE, vol. 6362, doi:10.1117/12.688953, 2006.

Garcia, R. R., Marsh, D. R., Kinnison, D. E., Boville, B. A., and Sassi, F.: Simulation of secular trends in the middle atmosphere, 1950-2003, J. Geophys. Res., 112, D09301, doi:10.1029/2006JD007485, 2007.

Gault, W. A., Brown, S., Moise, A., Liang, D., Sellar, G., Shepherd, G. G., and Wimperis, J.: ERWIN: an E-region wind interferometer, Appl. Opt. 35, 2913-2922, doi:10.1364/AO.35.002913, 1996a.

Gault, W. A., Thuillier, G., Shepherd, G. G., Zhang, S. P., Wiens, R. H., Ward, W. E., Tai, C., Solheim, B. H., Rochon, Y. J., McLandress, C., Lathuillere, C., Fauliot, V., Herse, M., Hersom, C. H., Gattinger, R., Bourg, L., Burrage, M. D., Franke, S. J., Hernan- dez, G., Manson, A., Niciejewski, R., and Vincent, R. A.: Validation of $\mathrm{O}\left({ }^{1} \mathrm{~S}\right)$ wind measurements by WINDII: the WIND Imaging Interferometer on UARS, J. Geophys. Res., 101, 1040510430, doi:10.1029/95JD03352, 1996 b.

Gentry, B., Chen, H., and Li, S.: Wind measurements with 355-nm molecular Doppler lidar, Opt. Lett., 25, 1231-1233, doi:10.1364/OL.25.001231, 2000.

Hibbins, R. E., Shanklin, J. D., Espy, P. J., Jarvis, M. J., Riggin, D. M., Fritts, D. C., and Lübken, F.-J.: Seasonal variations in the horizontal wind structure from $0-100 \mathrm{~km}$ above Rothera station, Antarctica $\left(67^{\circ} \mathrm{S}, 68^{\circ} \mathrm{W}\right)$, Atmos. Chem. Phys., 5, 2973-2980, doi:10.5194/acp-5-2973-2005, 2005.

Hibbins, R. E., Espy, P. J., and Jarvis, M. J.: Mean winds and tides in the mesosphere and lower thermosphere above Halley, Antarctica, J. Atmos. Sol.-Terr. Phy., 68, 436-444, doi:10.1016/j.jastp.2005.02.030, 2006.

Hibbins, R. E., Jarvis, M. J., and Ford, E. A. K.: Quasi-biennial oscillation influence on long-period planetary waves in the Antarctic upper mesosphere, J. Geophys. Res., 114, D09109, doi:10.1029/2008JD011174, 2009.

Hildebrand, J., Baumgarten, G., Fiedler, J., Hoppe, U.-P., Kaifler, B., Lübken, F.-J., and Williams, B. P.: Combined wind measurements by two different lidar instruments in the Arctic middle atmosphere, Atmos. Meas. Tech., 5, 2433-2445, doi:10.5194/amt5-2433-2012, 2012.

Hoffmann, P., Singer, W., Keuer, D., Hocking, W. K., Kunze, M., and Murayama, Y.: Latitudinal and longitudinal variability of mesospheric winds and temperatures during stratospheric warming events, J. Atmos. Sol.-Terr. Phy., 69, 2355-2366, doi:10.1016/j.jastp.2007.06.010, 2007.

Holton, J. R.: An introduction to dynamic meteorology, Elsevier, 4th ed., ISBN-13: 9780080470214, 2004.

Hooper, D. A., Nash, J., Oakley, T., and Turp, M.: Validation of a new signal processing scheme for the MST radar at Aberystwyth, Ann. Geophys., 26, 3253-3268, doi:10.5194/angeo-263253-2008, 2008.

Jacobi, C., Froehlilch, K., Viehweg, C., Stober, G., and Kuerschner, D.: Midlatitude mesosphere/lower thermosphere meridional winds and temperatures measured with meteor radar, Adv. Space Res., 39, 1278-1283, doi:10.1016/j.asr.2007.01.003, 2007.

Killeen, T. L., Wu, Q., Solomon, S. C., Ortland, D. A., Skinner, W. R., Niciejewski, R. J., and Gell, D. A.: TIMED Doppler Interferometer: Overview and recent results, J. Geophys. Res., 111, A10S01, doi:10.1029/2005JA011484, 2006.

Klein, B., Hochgürtel, S., Krämer, I., Bell, A., Meyer, K., and Güsten, R.: High-resolution wide-band fast Fourier transform spectrometers, Astron. Astrophys., 542, L3, doi:10.1051/00046361/201218864, 2012.

Kraus, J. D.: Radio astronomy, Powell, Ohio, Cygnus-Quasar, 2nd edition, ISBN-10: 1882484002, ISBN-13: 9781882484003 , June 1986.

Lamarque, J.-F., Emmons, L. K., Hess, P. G., Kinnison, D. E., Tilmes, S., Vitt, F., Heald, C. L., Holland, E. A., Lauritzen, P. H., Neu, J., Orlando, J. J., Rasch, P. J., and Tyndall, G. K.: CAM-chem: description and evaluation of interactive atmospheric chemistry in the Community Earth System Model, Geosci. Model Dev., 5, 369-411, doi:10.5194/gmd-5-369-2012, 2012. 
Lee, C. F., Vaughan, G., and Hooper, D. A.: Evaluation of wind profiles from the NERC MST radar, Aberystwyth, UK, Atmos. Meas. Tech., 7, 3113-3126, doi:10.5194/amt-7-3113-2014, 2014.

Le Pichon, A., Vergoz, J., Cansi, Y., Geranna, L., and Drob, D.: Contribution of infrasound monitoring for atmospheric remote sensing, in Infrasound Monitoring for Atmospheric Studies, edited by: Le Pichon, A., Blanc, E., and Hauchecorne, A., 629-646, Springer, New York, 2010.

Le Pichon, A., Assink, J. D., Heinrich, P., Blanc, E., CharltonPerez, A., Lee, C. F., Keckhut, P., Hauchecorne, A., Rüfenacht, R., Kämpfer, N., Drob, P., Smets, P. S. M., Evers, L. G., Ceranna, L., Pilger, C., Ross, O., and Claud, C.: Comparison of co-located independent ground-based middle atmospheric wind and temperature measurements with numerical weather prediction models, J. Geophys. Res.-Atmos., 120, 8318-8331, doi:10.1002/2015JD023273, 2015.

Liebe, H. J., Hufford, G. A., and Cotton, M. G.: Propagation modelling of moist air and suspended water/ice particles at frequencies below $1000 \mathrm{GHz}$, in: AGARD 52nd Specialists' Meeting of the Electromagnetic Wave Propagation Panel, Palma de Mallorca, Spain, 3.1-3.10, 17-21 May 1993.

McDade, I. C., Shepherd, G. G., Gault, W. A., Rochon, Y. J., McLandress, C., Scott, A., Rowlands, N., and Buttner, G.: The stratospheric wind interferometer for transport studies SWIFT), in: Igarss 2001: Scanning the Present and Resolving the Future, Vol. 3, Proceedings, 1344-1346, Sydney NSW, 9-13 July, doi:10.1109/IGARSS.2001.976839, 2001.

Maekawa, Y., Fukao, S., Yamamoto, M., Yamanaka, M. D., Tsuda, T., Kato, S., and Woodman, R. F.: First observation of the upper stratospheric vertical wind velocities using the Jicamarca VHF radar, Geophys. Res. Lett., 20, 2235-2238, doi:10.1029/93GL02606, 1993.

Manney, G. L., Krüger, K., Pawson, S., Minschwaner, K., Schwartz, M. J., Daffer, W. H., Livesey, N. J., Mlynczak, M. G., Remsberg, E. E., Russell, J. M., and Waters, J. W.: The evolution of the stratopause during the 2006 major warming: Satellite data and assimilated meteorological analyses, J. Geophys. Res.-Atmos., 113, D11115, doi:10.1029/2007JD009097, 2008.

Marsh, D.: Chemical-dynamical coupling in the mesosphere and lower thermosphere, Aeronomy of the Earth's Atmosphere and Ionosphere, IAGA Special Sopron Book Series, 2, 3-17, doi:10.1007/978-94-007-0326-1, 2011.

Melsheimer, C. , Verdes, C. , Buehler, S. A., Emde, C., Eriksson, P., Feist, D. G., Ichizawa, S., John, V. O., Kasai, Y., Kopp, G., Koulev, N., Kuhn, T., Lemke, O., Ochiai, S., Schreier, F., Sreerekha, T. R., Suzuki, M., Takahashi, C., Tsujimaru, S., and Urban, J.: Intercomparison of general purpose clear sky atmospheric radiative transfer models for the millimeter/submillimeter spectral range, Radio Sci., 40, RS1007, doi:10.1029/2004RS003110, 2005.

Minschwaner, K., Manney, G. L., Livesey, N. J., Pumphrey, H. C., Pickett, H. M., Froidevaux, L., Lambert, A., Schwartz, M. J., Bernath, P. F., Walker, K. A., and Boone, C. D.: The photochemistry of carbon monoxide in the stratosphere and mesosphere evaluated from observations by the Microwave Limb Sounder on the Aura satellite, J. Geophys. Res., 115, D13303, doi:10.1029/2009JD012654, 2010.
Müllemann, A. and Lübken, F.-J.: Horizontal winds in the mesosphere at high latitudes, Adv. Space Res., 35, 1890-1894, doi:10.1016/j.asr.2004.11.014, 2005.

Navas-Guzmán, F., Kämpfer, N., Murk, A., Larsson, R., Buehler, S. A., and Eriksson, P.: Zeeman effect in atmospheric $\mathrm{O}_{2}$ measured by ground-based microwave radiometry, Atmos. Meas. Tech., 8 , 1863-1874, doi:10.5194/amt-8-1863-2015, 2015.

Newnham, D. A., Espy, P. J., Clilverd, M. A., Rodger, C. J., Seppälä, A., Maxfield, D. J., Hartogh, P., Holmén, K., and Horne, R. B.: Direct observations of nitric oxide produced by energetic electron precipitation into the Antarctic middle atmosphere, Geophys. Res. Lett., 38, L20104, doi:10.1029/2011GL048666, 2011.

Nicolls, M. J., Varney, R. H., Vadas, S. L., Stamus, P. A., Heinselman C. J., Cosgrove, R. B., and Kelley, M. C.: Influence of an inertia-gravity wave on mesospheric dynamics: A case study with the Poker Flat Incoherent Scatter Radar, J. Geophys. Res., 115, D00N02, doi:10.1029/2010JD014042, 2010.

Nielsen, K., Taylor, M. J., Hibbins, R. E., Jarvis, M. J., and Russell III, J. M.: On the nature of short-period mesospheric gravity wave propagation over Halley, Antarctica, J. Geophys. Res., 117, D05124, doi:10.1029/2011JD016261, 2012.

Pumphrey, H. C., Filipiak, M. J., Livesey, N. J., Schwartz, M. J., Boone, C., Walker, K. A., Bernath, P., Ricaud, P., Barret, B., Clerbaux, C., Jarnot, R. F., Manney, G. L., and Waters, J. W.: Validation of middle-atmosphere carbon monoxide retrievals from the Microwave Limb Sounder on Aura, J. Geophys. Res., 112, D24S38, doi:10.1029/2007JD008723, 2007.

Rienecker, M. M., Suarez, M. J., Gelaro, R., Todling, R., Bacmeister, J., Liu, E., Bosilovich, M. G., Schubert, S. D., Takacs, L. Kim, G.-K., Bloom, S., Chen, J., Collins, D., Conaty, A., da Silva, A., Gu, W., Joiner, J., Koster, R. D., Lucchesi, R., Molod, A., Owens, T., Pawson, S., Pegion, P., Redder, C. R., Reichle, R., Robertson, F. R., Ruddick, A. G., Sienkiewicz, M., and Woollen, J.: MERRA: NASA's Modern-Era Retrospective Analysis for Research and Applications, J. Climate, 24, 3624-3648, doi:10.1175/JCLI-D-11-00015.1, 2011.

Rodgers, C. D.: Inverse methods for atmospheric sounding: Theory and Practice, vol. 2 of Series on Atmospheric, Ocean and Planetary Physics, World Scientific, 256 pp., ISBN-13: 978-98102-2740-1, 2000.

Rosenkranz, P. W.: Absorption of Microwaves by Atmospheric, in: Atmospheric Remote Sensing by Microwave Radiometry, edited by: Janssen, M. A., p. 37, Wiley-Blackwell, 1993.

Rosenkranz, P. W.: Water vapor microwave continuum absorption: A comparison of measurements and models, Radio Sci., 33, 919928, doi:10.1029/98RS01182, 1998.

Rothman, L. S. Gordon, I. E., Babikov, Y., Barbe, A., Chris Benner, D., Bernath, P. F., Birk, M., Bizzocchi, L., Boudon, V., Brown, L. R., Campargue, A., Chance, K., Cohen, E. A., Coudert, L. H., Devi, V. M., Drouin, B. J., Fayt, A., Flaud, J.M., Gamache, R. R., Harrison, J. J., Hartmann, J.-M., Hill, C., Hodges, J. T., Jacquemart, D., Jolly, A., Lamouroux, J., Le Roy, R. J., Li, G., Long, D. A,. Lyulin, O. M., Mackie, C. J., Massie,S. T., Mikhailenko, S., Müller, H. S. P., Naumenko, O. V., Nikitin, A. V., Orphal, J., Perevalov, V., Perrin, A., Polovtseva, E. R., Richard, C., Smith, M. A. H., Starikova, E., Sung, K., Tashkun, S., Tennyson, J., Toon, G. C., Tyuterev, Vl. G., and Wagner, G.: The HITRAN2012 molecu- 
lar spectroscopic database, J. Quant. Spectrosc. Ra., 130, 4-50, doi:10.1016/j.jqst.2013.07.002, 2013.

Rüfenacht, R., Kämpfer, N., and Murk, A.: First middleatmospheric zonal wind profile measurements with a new ground-based microwave Doppler-spectro-radiometer, Atmos. Meas. Tech., 5, 2647-2659, doi:10.5194/amt-5-2647-2012, 2012.

Rüfenacht, R., Murk, A., Kämpfer, N., Eriksson, P., and Buehler, S. A.: Middle-atmospheric zonal and meridional wind profiles from polar, tropical and midlatitudes with the ground-based microwave Doppler wind radiometer WIRA, Atmos. Meas. Tech., 7, 4491-4505, doi:10.5194/amt-7-4491-2014, 2014.

Sandford, D. J., Beldon, C. L., Hibbins, R. E., and Mitchell, N. J.: Dynamics of the Antarctic and Arctic mesosphere and lower thermosphere - Part 1: Mean winds, Atmos. Chem. Phys., 10, 10273-10289, doi:10.5194/acp-10-10273-2010, 2010.

Shepherd, G. G., McDade, I. C., Gault, W. A., Rochon, Y. J., Scott, A., Rowlands, N., and Buttner, G.: The Stratospheric Wind Interferometer For Transport studies (SWIFT), Adv. Space Res., 27, 1071-1079, doi:10.1016/S0273-1177(01)00140-5, 2001.

Souprayen, C., Garnier, A., Hertzog, A., Hauchecorne, A., and Porteneuve, J.: Rayleigh-Mie Doppler wind lidar for atmospheric measurements, I.: Instrumental setup, validation, and first climatological results, Appl. Opt., 38, 2410-2421, doi:10.1364/AO.38.002410, 1999.

Stoffelen, A., Pailleux, J., Källén, E., Vaughan, J., Isaksen, L., Flamant, P., Wergen, W., Andersson, E., Schyberg, H., Culoma, A., Meynart, R., Endemann, M., and Ingmann, P.: The atmospheric dynamics mission for global wind field measurement, B. Am. Meteorol. Soc., 86, 73-87, doi:10.1175/BAMS-86-1-73, 2005.
Straub, C., Espy, P. J., Hibbins, R. E., and Newnham, D. A.: Mesospheric CO above Troll station, Antarctica observed by a ground based microwave radiometer, Earth Syst. Sci. Data, 5, 199-208, doi:10.5194/essd-5-199-2013, 2013.

Swinbank, R. and Ortland, D. A.: Compilation of wind data for the Upper Atmosphere Research Satellite (UARS) Reference Atmosphere Project, J. Geophys. Res.-Atmos., 108, 4615, doi:10.1029/2002JD003135, 2003.

Turunen, E., Verronen, P. T., Seppälä, A., Rodger, C. J., Clilverd, M. A., Tamminen, J., Enell, C.-F., and Ulich, T.: Impact of different energies of precipitating particles on $\mathrm{NO}_{x}$ generation in the middle and upper atmosphere during geomagnetic storms, J. Atmos. Sol.-Terr. Phy., 71, 1176-1189, doi:10.1016/j.jastp.2008.07.005, 2009.

Williams, B. P., Fritts, D. C., Wang, L., She, C. Y., Vance, J. D., Schmidlin, F. J., Goldberg, R. A., Müllemann, A., and Lübken, F.-J.: Gravity waves in the arctic mesosphere during the MaCWAVE/MIDAS summer rocket program, Geophys. Res. Lett., 31, L24S05, doi:10.1029/2004GL020049, 2004.

Wu, D. L., Schwartz, M. J., Waters, J. W., Limpasuvan, V., Wu, Q., and Killeen, T. L.: Mesospheric Doppler wind measurements from Aura microwave limb sounder (MLS), Adv. Space Res., 42, 1246-1252, doi:10.1016/j.asr.2007.06.014, 2008. 